Review Article

\title{
Low-Temperature Brazing of Titanium Using Al-Based Filler Alloys
}

\author{
A. Muhrat $\mathbb{D}^{\mathrm{D}}$, H. Puga $(\mathbb{D}$, and J. Barbosa \\ Centre for Micro-Electro-Mechanical Systems (CMEMS), The University of Minho, Campus of Azurém, \\ 4800-058 Guimarães, Portugal
}

Correspondence should be addressed to A. Muhrat; eng.abdulsalam.edu@gmail.com

Received 1 December 2017; Accepted 23 January 2018; Published 12 April 2018

Academic Editor: Fantao Kong

Copyright (c) 2018 A. Muhrat et al. This is an open access article distributed under the Creative Commons Attribution License, which permits unrestricted use, distribution, and reproduction in any medium, provided the original work is properly cited.

Brazing of titanium using low melting temperature filler alloys is a preferred choice regarding cost and preserving its mechanical properties. However, brazing titanium at low temperature is still a challenge, especially regarding aluminum-based filler alloys. During the last years, several brazing methods and Al-based fillers were developed to meet industrial requirements; some of them might achieve some of those requirements. The use of ultrasound in brazing has gained increased attention recently, which helps to reduce the time and the necessity for a special brazing environment, subsequently, reducing cost and increasing applicability. Brazing titanium below the $\alpha \leftrightarrow \beta$ transformation temperature, using commercial and experimental Al-based fillers of different compositions, is presented in this review; including the procedures of traditional and ultrasound-assisted brazing methods. Correspondingly, the effects of brazing conditions and alloying elements on the mechanical properties and the intermetallic compounds formation are examined.

\section{Introduction}

Brazing of titanium at a temperature below $\alpha \leftrightarrow \beta$ transformation temperature has great importance in avoiding undesirable changes in its original microstructures $[1,2]$. A low brazing temperature is particularly crucial for thin-wall brazing structures of aerospace components and heat exchangers [3]. The shorter brazing cycle/less brazing temperature helps to prevent the excess interaction between the joint components and growth of the intermetallic compounds at the joint interface [2]. Titanium has a strong chemical attraction of oxygen; therefore, even at room temperature, a passive amorphous oxide layer forms rapidly on its surface [4]. The oxidation of the surface makes titanium joining process challenging from the point of establishing the metal connection; furthermore, titanium should be protected from severe oxidation at temperatures exceeding $650^{\circ} \mathrm{C}$ [5]. In addition to susceptibility to grain coarsening and affecting strength/ductility of the parent components, high-temperature brazing requires special equipment, conditions, and longer processing time, leading to higher processing cost compared with low-temperature brazing.
Titanium joining has been widely studied [6]. Unlike brazing, welding is not used usually for titanium honeycomb sandwich structures [7-10] which require joining many points without distortion. Moreover, the welding process is not suitable for joining titanium aluminides [11]. A great number of brazing filler alloys were developed and studied for brazing titanium alloys; some of them were commercially used. In 1950s and 1960s, early work was focused upon Ag-, $\mathrm{Au}-, \mathrm{Cu}-$, and $\mathrm{Pd}$-based filler alloys for $\sim\left(316-427^{\circ} \mathrm{C}\right)$ and $\mathrm{Al}-$ based filler alloys for $\sim 204^{\circ} \mathrm{C}$ service temperatures. Ti- and Ti-Zr-based alloys were developed later, which showed better metallurgical compatibility with titanium [12] and produced higher joint strength when compared with the other systems of brazing fillers. Table 1 shows some examples of relatively high strength and temperature brazed joints using Ti- and Ti-Zr-based filler alloys. However, low-temperature brazing with more free conditions could find several applications: where the inert atmosphere cannot be applied, the parts to be joined cannot fit within limited and special environments such as the mass production by continuous brazing, the large brazing joints, or for in-place brazing. Furthermore, reducing the joining cost by lowering 
temperature is important for reducing the total fabrication cost and maintaining titanium share in the total structural weight of aerospace systems [13].

According to the main alloying elements, filler alloys for brazing titanium and its alloys can mainly be classified into five groups: titanium-based $[1,14,16,18-21]$, zirconiumbased [16, 19, 22, 23], silver-based [24-27], aluminum-based [28-31], and nickel-based [19, 32] filler alloys. Attempts of brazing titanium using Al-based filler alloys and other filler systems started over than 60 years ago [33]. Many Al-based filler alloys have been developed since that time, and many attempts were made in pursuit of achieving suitable brazing conditions. Titanium was brazed to itself and to aluminum alloys by Al-based fillers using an oxyacetylene torch with flux [30, 33], in high-purity argon [10, 33], in vacuum [28-31, 34-36], and in air conditions: in fluxless process assisted by the ultrasonic vibration (USV) [37-39] or by additional pressure [40]. Investigating and improving the mechanical properties of the produced joint through a careful design of the brazing cycle and controlling the intermetallic compound formation/diffusion zone were among the primary explored objectives in brazing titanium and its alloys. Considerable efforts have been made to reduce brazing cycle time while still achieving a suitable strength by employing new techniques and developing new compositions of low-melting filler materials. Although significant work has been done so far, brazing of titanium by Al-based fillers still needs more development to increase its share in the industrial sector.

The developed microstructure and mechanical properties of brazing joints depend on the component compositions, temperature-time cycle, and the joint design. Choosing the right cycle parameters depends, in turn, on the rate and nature of the interaction at parent/filler interface. The short temperature-time brazing cycle protects the parent component from unwanted metallurgical changes, which may occur faster as the temperature increases; for instance, the aging effects which take place in $4 \mathrm{~h}$ at $537.8^{\circ} \mathrm{C}\left(1000^{\circ} \mathrm{F}\right)$ in Ti-6Al-4V would occur in $\sim 10 \mathrm{~min}$ at $579.4^{\circ} \mathrm{C}\left(1075^{\circ} \mathrm{F}\right)$ [41]. However, brazing time could be increased according to the parent/filler materials' compositions to allow the interface element diffusion to take place for a certain limit which is necessary to achieve the optimal joint strength. The diffusion of some brazing processes, usually in high temperature, may proceed for a relatively long holding time until achieving the microstructure homogenization over all the joint, which is particularly known as diffusion brazing. Matsu et al., Ganjeh et al. and Chang et al. [16, 17, 42] investigated the diffusion brazing of several Ti- and Zr-based fillers, which led to specific microstructures and high shear strengths (Table 1). These processes involve isothermal solidification and homogenization of the joint [43].

In metal casting, the ultrasonic vibration (USV) provides multiple significant effects such as degassing [44-47], refining, and modifying the microstructures [48-51]. Using USV in brazing is an attractive assisting tool [37-39, 52-58]; however, studying the combined effects of USV with the technological parameters of brazing process and developing a joint interface more compatible with the USV have not yet received an adequate attention. The focus in this review will be on the titanium/aluminum interface which includes Albased filler alloys for brazing titanium/titanium and titanium/aluminum parent (base) components, taking into consideration the technological parameters and procedures.

\section{Aluminum-Based Filler Alloys}

Various Al-based alloy systems have been tested for brazing titanium/titanium and titanium/aluminum parent components. The alloying additions to the filler materials serve several purposes, such as reducing melting temperature, improving wetting $[28,34]$, reducing intermetallic thickness [29], improving corrosion resistance [41], and improving static/dynamic strength at work temperature [29].

Lowering the brazing temperature and reducing the contact time of a molten filler alloy with a parent titanium alloy reduce the Ti erosion $[26,42]$ and increase the reliability of the thin-wall titanium joints [3]. Al-based filler alloys can be a suitable candidate for brazing titanium satisfying the following conditions: the melting temperature considerably below the $\alpha \leftrightarrow \beta$ transformation temperature of titanium alloys, a good metallurgical compatibility with titanium alloys, good wetting and spreading on titanium surface, good corrosion resistance [59], low density, and acceptable strength for a large joining surface [2]. Some commercial Al-based filler alloys of $\mathrm{Al}-\mathrm{Cu}, \mathrm{Al}-\mathrm{Mg}$, and $\mathrm{Al}-\mathrm{Si}$ systems with addition of $\mathrm{Cr}$ and $\mathrm{Ti}$ were introduced $[3,19]$. However, aluminum leads to fast formation of a brittle intermetallic layer at the joint interface with $\mathrm{Ti}$ and provides relatively low strength compared with other filler alloys; the activity of $\mathrm{Al}$ with $\mathrm{Ti}$ is considered the dominant challenge when designing Al-based fillers and optimizing the brazing process.

\subsection{The Developing of Brazing Conditions/Methods in Brazing Ti/Ti and Ti/Al Using Aluminum-Based Fillers}

2.1.1. Vacuum, Torch Brazing, and Other Methods. Lewis et al. [33] tested initially many of commercially available brazing fillers using careful sample preparation procedures. The obtained shear strength of the double-lap-brazed joints in a controlledatmosphere furnace brazing was $73.77-115.69 \mathrm{MPa}$ using $61 \mathrm{~S}$ (6061) aluminum filler. Further torch-brazing tests were made by covering the specimen surfaces with a commercial titanium flux and using a slightly reducing flame. In general, the strength results were lower $44.82-88.94 \mathrm{MPa}$ when compared with the controlled-atmosphere furnace brazing; the reason was explained by flux entrapment in the joint area or insufficient temperature control and oxidation protection in torch brazing. The use of torch brazing must always be accompanied by specific fluxes, choosing the suitable flux should consider the alloying elements in the molten filler and should be suitable for all joint elements. Fluxes for titanium are primarily mixtures of fluorides and chlorides of the alkali metals, sodium, potassium, and lithium [4].

Takemoto et al. [28] investigated brazing of pure Ti/Al3003 $(\mathrm{Al}-1 \mathrm{Mn})$ joint in vacuum using three different $\mathrm{Al}$-based filler alloys. Brazing time was short (3-5 min) and brazing temperature did not exceed $615^{\circ} \mathrm{C}$. Table 2 shows the shear strength results. 
TABLE 1: Examples of high-temperature brazing of titanium.

\begin{tabular}{|c|c|c|c|c|}
\hline $\begin{array}{l}\text { Shear strength } \\
\text { (MPa) }\end{array}$ & Conditions & Filler & Parent metal & References \\
\hline 300 & $\begin{array}{c}\text { Vacuum }+\operatorname{argon}, 880^{\circ} \mathrm{C}, \\
60 \mathrm{~min}\end{array}$ & $37.5 \mathrm{Ti}-37.5 \mathrm{Zr}-15 \mathrm{Cu}-10 \mathrm{Ni}$ & Commercially pure titanium (Grade 2) & {$[14]$} \\
\hline 261.7 & $\begin{array}{c}\text { Vacuum }+\operatorname{argon}, 870^{\circ} \mathrm{C}, \\
30 \mathrm{~min}\end{array}$ & $\mathrm{Ti}-27 \mathrm{Zr}-14 \mathrm{Cu}-13 \mathrm{Ni}$ & Commercially pure titanium (Grade 2) & [15] \\
\hline 540 & Argon, $950^{\circ} \mathrm{C}, 30 \mathrm{~min}$ & $\mathrm{Ti}-26.8 \mathrm{Zr}-13 \mathrm{Ni}-13.9 \mathrm{Cu}$ & $\mathrm{Ti}-6 \mathrm{Al}-4 \mathrm{~V}$ (Grade 5) & {$[16]$} \\
\hline 545 & Vacuum, $1030^{\circ} \mathrm{C}, 3 \mathrm{~min}$ & $\mathrm{Ti}-15 \mathrm{Cu}-25 \mathrm{Ni}$ & $\begin{array}{c}\mathrm{Ti}-6 \mathrm{Al}-4 \mathrm{~V}(\mathrm{Grade} \\
5) / \mathrm{Ti}-15 \mathrm{~V}-3 \mathrm{Al}-3 \mathrm{Cr}-3 \mathrm{Sn}\end{array}$ & [17] \\
\hline
\end{tabular}

Pure Ti/Ti joints were investigated under the same level of vacuum using pure aluminum and $\mathrm{Al}-0.8 \% \mathrm{Si}$ as filler materials at $680^{\circ} \mathrm{C}$ and $3 \mathrm{~min}$ holding time [28, 29]. The reported shear strength was $\sim 92 \mathrm{MPa}$ for both filler metals; anyway, increasing the holding time leaded to drastic decrement rate of the joint strength of the pure $\mathrm{Al}$ filler. It was found that the use of pure $\mathrm{Al}$ as a filler metal to braze $\mathrm{Ti} / \mathrm{Ti}$ in $700^{\circ} \mathrm{C}$ leaded to self-separation of the joint after holding time of $30 \mathrm{~min}$, and the thickness of the formed intermetallic compound layer $\left(\mathrm{TiAl}_{3}\right)$ was the greatest, which acts as an initiation site for cracks.

Sohn et al. [34] studied the diffusion between the $\mathrm{Al}-10 \mathrm{Si}-1 \mathrm{Mg}$ filler metal and the parent metals of $\mathrm{CP}$ $\mathrm{Ti} / \mathrm{Al} 1050$ by maintaining the temperature at $620^{\circ} \mathrm{C}$ and changing the holding time in $1 \times 10^{-4}$ Torr vacuum as it is presented in Figure 1.

The best-achieved shear strength was $84 \mathrm{MPa}$ for the brazing time of $25 \mathrm{~min}$. For longer brazing time, bond strength decreased due to the formation of cavities in $\mathrm{Al}$ near Al/intermetallic interface. Shiue et al. [35] investigated a fast heating approach in joining titanium aluminide Ti50-A150 by infrared brazing using pure aluminum and BAlSi-4 of the composition (Al- (11-13)Si-0.3Cu-0.1Mg$0.2 \mathrm{Zn}-0.15 \mathrm{Mn}-0.8 \mathrm{Fe}$ ) as filler alloys. Brazing was done in the vacuum using a high-speed infrared source for heating of $900^{\circ} \mathrm{C} / \mathrm{min}$, and preceded by a preheating for $60 \mathrm{~s} / 400^{\circ} \mathrm{C}$. For the pure aluminum filler, a large formation of the brittle intermetallic phase $\mathrm{TiAl}_{3}$ was found for all holding times, and the bonding strength was very weak. Figure 2 shows the place of the crack through the major phase of $\mathrm{TiAl}_{3}$ in the joint.

While for BAlSi-4 filler alloy which contains $\mathrm{Si}$, it was observed that the intermetallic $\mathrm{Ti}_{2} \mathrm{AlSi}_{3}$ was prominent at an early stage of infrared brazing. By increasing the time and temperature, the volume fraction of $\mathrm{Ti}_{2} \mathrm{AlSi}_{3}$ decreased dramatically and replaced by $\mathrm{Ti}_{5} \mathrm{Al}_{12} \mathrm{Si}_{3}$, and then it disappeared. The highest strength $86.2 \mathrm{MPa}$ was achieved for $900^{\circ} \mathrm{C}$ brazing temperature.

Khorunov et al. [31] investigated $\mathrm{Al}-\mathrm{Si}$ and $\mathrm{Al}-\mathrm{Mg}$ filler alloys in brazing OT4 (Ti-3Al-1.5Mn) titanium alloy in vacuum. The resulted strengths using $\mathrm{Al}-\mathrm{Mg}$ filler alloys were relatively high $(82-83 \mathrm{MPa})$, while the produced joint using $\mathrm{Al}-\mathrm{Si}$ filler alloy was characterized by inferior quality with a continuous layer of silicide detected along the interface.

Some efforts have been made to simplify brazing process and carry out titanium brazing in normal ambient air conditions. These efforts were focused on developing low-
TABle 2: Results of brazing Ti/Al3003 by Takemoto et al. [28].

\begin{tabular}{lcc}
\hline Shear strength $(\mathrm{MPa})$ & Brazing conditions & Fillers \\
\hline 38.25 & $615^{\circ} \mathrm{C}, 5 \mathrm{~min}$, vacuum & $\mathrm{Al}-10 \mathrm{Cu}-8 \mathrm{Sn}$ \\
38.25 & $600^{\circ} \mathrm{C}, 5 \mathrm{~min}$, vacuum & $\mathrm{Al}-20 \mathrm{Ag}-10 \mathrm{Cu}$ \\
69.88 & $600^{\circ} \mathrm{C}, 3 \mathrm{~min}$, vacuum & $\mathrm{Al}-10 \mathrm{Si}-0.5 \mathrm{Mg}$ \\
\hline
\end{tabular}

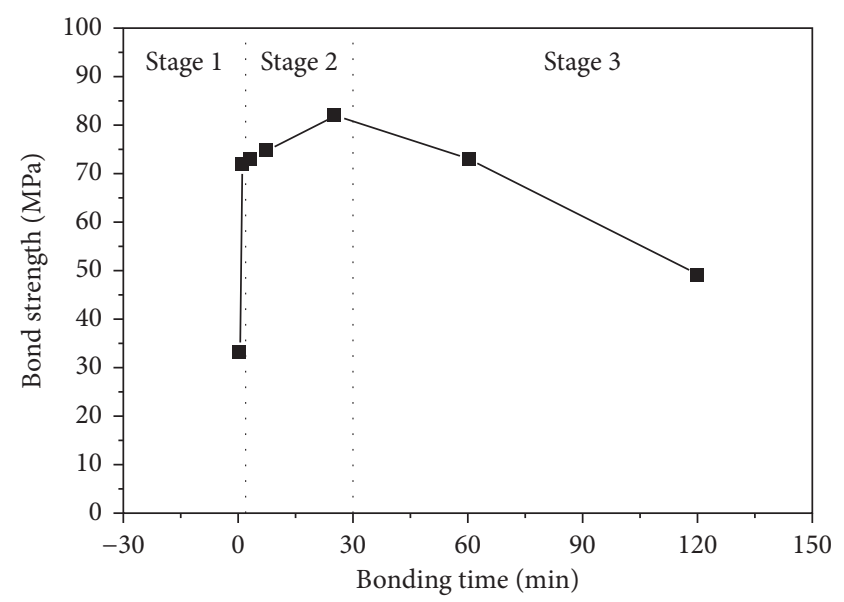

FIGURE 1: Shear strength variation of brazed joints CP-Ti/Al1050 at $620^{\circ} \mathrm{C}$ using Al-10Si-1Mg filler alloy. Reproduced from Sohn et al. [34], copyright 2003, with permission from Elsevier.

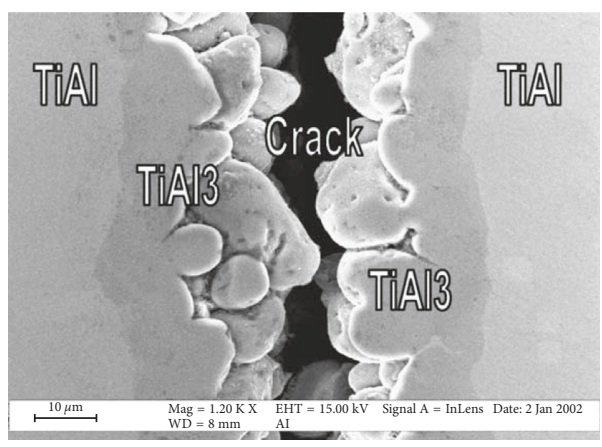

Figure 2: The crack location of the brazed joint Ti50Al50/Al/ Ti50Al50 $\left(900^{\circ} \mathrm{C}, 30 \mathrm{~s}\right)$. Reproduced from Shiue et al. [35], copyright 2003, with permission from Elsevier.

melting brazing fillers and finding a suitable technique to remove the oxide layer on the faying surfaces of the joint. In Germany, Bach et al. (cited in [2]) conducted an early attempt of Ti-6Al-4V brazing in the air by utilizing an alloy of 
TABLE 3: Recent studies of ultrasound-assisted brazing of Ti/Ti and Ti/Al joints by Al-based fillers.

\begin{tabular}{|c|c|c|c|}
\hline Reference & Materials & Heating method and best conditions (all in air) & $\begin{array}{l}\text { Shear strength } \\
(\mathrm{MPa})\end{array}$ \\
\hline [37] & $\begin{array}{l}\text { Parent metal: Ti Grade 5; } \\
\text { filler metal: TiBraze Al-665(Al-2.5Mg-0.3Cr) } / 100 \mu \mathrm{m}\end{array}$ & $\begin{array}{c}\text { Induction brazing, } 660^{\circ} \mathrm{C},(5 \mathrm{sec}, 84 \mathrm{~W}) \mathrm{USV} \text {, } \\
\text { no holding time }\end{array}$ & $50-60$ \\
\hline [39] & $\begin{array}{c}\text { Parent metals: Ti Grade 5/Al1060; } \\
\text { filler metal: Al-12Si }\end{array}$ & $\begin{array}{c}(A=6 \mu \mathrm{m}, 20 \mathrm{kHz}) \mathrm{USV}, 620^{\circ} \mathrm{C}, 4 \mathrm{sec} \text { USV + holding } \\
\text { for } 15 \text { or } 5 \mathrm{~min}+4 \text { or } 0 \mathrm{sec} \text { USV }\end{array}$ & $\sim 68$ \\
\hline [38] & $\begin{array}{l}\text { Parent metal: Ti Grade 2; } \\
\text { filler metal: TiBraze Al-665A } \\
\text { (Al-2.5Mg-0.3Cr) } / 50 \mu \mathrm{m}\end{array}$ & $\begin{array}{l}\text { Induction brazing, }(25 \mathrm{kHz}, 120 \mathrm{~W}) \mathrm{USV}, 670^{\circ} \mathrm{C} \text {, } \\
\text { holding for } 5 \mathrm{~min} \text { at } 560^{\circ} \mathrm{C} \text {, then heating to } 670^{\circ} \mathrm{C} \text { and } \\
\text { holding for } 3 \mathrm{~min} \text {, applying USV for } 6 \mathrm{~s}\end{array}$ & $\sim 64$ \\
\hline$[55]$ & $\begin{array}{l}\text { Parent metals: Ti Grade 5/Al6061; } \\
\text { filler metal: } \mathrm{Al}-9.4 \mathrm{Si}-10 \mathrm{Zn}-10 \mathrm{Cu}-2 \mathrm{Ni}\end{array}$ & $\begin{array}{c}(A=6 \mu \mathrm{m}, 20 \mathrm{kHz}) \mathrm{USV}, 560^{\circ} \mathrm{C}, 4 \mathrm{sec} \text { USV + holding } \\
\text { for } 60 \mathrm{~min}+4 \mathrm{sec} \text { USV }\end{array}$ & $\sim 43$ \\
\hline [55] & $\begin{array}{l}\text { Parent metals: Ti Grade 5/Al6061; } \\
\text { filler metal: } \mathrm{Al}-15 \mathrm{Sn}-8.2 \mathrm{Si}-8.5 \mathrm{Zn}-8.5 \mathrm{Cu}-1.7 \mathrm{Ni}\end{array}$ & $\begin{array}{c}(A=6 \mu \mathrm{m}, 20 \mathrm{kHz}) \mathrm{USV}, 560^{\circ} \mathrm{C}, 4 \mathrm{sec} \text { USV + holding } \\
\text { for } 15 \mathrm{~min}+4 \mathrm{sec} \text { USV }\end{array}$ & $\sim 76$ \\
\hline
\end{tabular}

low-melting temperature, which was a thin $\mathrm{Al}$ foil coated with copper $(33 \% \mathrm{Cu})$ for a brazing gap of $6-20 \mu \mathrm{m}$. The produced joint had a good quality; anyway, the shear strength did not reach more than $25 \mathrm{MPa}$, which serves in joining large areas only. This showed that the eutectic $\mathrm{Al}-\mathrm{Cu}$ was active enough to react with titanium in the air. Karfoul and Muhrat [40] investigated Ti/Ti-brazed joint strength in relation to the filler metal compositions and brazing parameters in the air. New brazing filler alloys of $\mathrm{Al}-\mathrm{Cu}-\mathrm{Ni}-\mathrm{Ti}$ group were studied to find the effects of the alloying elements, as well as investigating the possibility of brazing in the air. The highest average shear strength achieved was $\sim 74-73 \mathrm{MPa}$ using $\mathrm{Al}-8.54 \mathrm{Cu}-1.35 \mathrm{Ni}-0.08 \mathrm{Ti}$ and $\mathrm{Al}-$ $6.44 \mathrm{Cu}-1.96 \mathrm{Ni}-0.92 \mathrm{Ti}$ filler alloys. Removing the oxide layers between the aluminum and titanium is the initiation key of the bonding process. Accordingly, adding pressure will lead, with the help of Ti surface roughness, to break the oxide layer of Al-based filler. Then, buckling proceeds through thickness cracking of the scale, and the stripped $\mathrm{Al}$ surface atoms will react with the Ti-oxide layer to reduce it to atomic Ti [40]. Using USV as an assistant tool in brazing, which leads to fast breaking of the oxide layer at the joint interface and makes the joining process possible in air conditions, is summarized in the following.

2.1.2. Ultrasound-Assisted Brazing of $\mathrm{Ti}$ by Al-Based Fillers. The sonochemical effects of the USV in liquids have been explored for over 80 years [60]. The interest in ultrasound-assisted brazing started more than 50 years ago. One of the early US patents was an ultrasound-assisted brazing unit using an ultrasonic tip surrounded by local heating flame [61].

Using USV for a short period results in very fast destroying of the oxide layer on the parent material and wetting it by the filler material [52], even it is effective in achieving a good wetting on ceramics by the filler materials in the air $[53,54,62]$. The acoustic cavitation generated in the liquid metal is considered as the most important physical effect of the ultrasonic oscillation propagation [63-66]. The formation of cavities starts with the half period of rarefaction at the weakest points of the melt [63]. Cavities continue to increase in size until they collapse by the compressing stresses during the next compression half period; the results of this collapse include high-intensity pressure pulses, temperature spikes, and high-velocity jets. The important physical and chemical processes due to the ultrasonic cavitation are melt degassing, filtration, wetting of the solid inclusions, and structure modifications. Moreover, the acoustic cavitation results in ultrasound energy adsorption and formation of acoustic streaming. The sound pressure must exceed a certain level to be able to initiate cavitation in the liquid metal, which is called cavitation threshold [63].

Employing USV in brazing results in short processing time, consequently, reducing the cost, and preserving the parent components from further metallurgical changes. The advantages include less specific atmosphere requirements due to the fast-breaking of the oxide layer [39, 52], enhanced spreading of the molten filler $[55,62]$, and homogenizing the microstructures of the joint [39]. Table 3 summarizes the technological parameters and the shear strength results of the ultrasound-assisted brazing of $\mathrm{Ti} / \mathrm{Ti}$ and $\mathrm{Ti} / \mathrm{Al}$ joints using Al-based fillers.

Chen et al. [52] explored the instantaneous breakage behavior of the oxide film of Ti-6Al-4V on its interface with the liquid Al-Si alloy and the chemical interactions during the process using $20 \mathrm{kHz}$ frequency and 5.5-7 $\mu \mathrm{m}$ amplitude USV. The samples were heated to $620^{\circ} \mathrm{C}$ then the titanium sonotrode was quickly loaded on the titanium substrate with a constant pressure of $0.2 \mathrm{MPa}$. The applied time of USV was $2-16 \mathrm{~s}$. Due to the USV effect, a large number of pits were formed on the titanium substrate as it is shown in Figure 3. The formation of the pit started by a small notch on the surface of the Ti oxide film due to "cavitation erosion" $[65,67]$ ( $\mathrm{N}$ in Figure 4 ) which serves as a microchannel and allows direct interaction between the fresh $\mathrm{Ti}$ surface and molten $\mathrm{Al}$ alloy.

The suggested pit formation mechanism according to this study was firstly, the formation of a notch at the oxide layer of the titanium substrate and secondly, violent chemical dissolution of the solid phase Ti-6Al-4V into the liquid filler $\mathrm{Al}-\mathrm{Si}$, followed by further interfacial chemical reactions.

Chen et al. [39] conducted a further work in ultrasound-assisted brazing of $\mathrm{Ti}-6 \mathrm{Al}-4 \mathrm{~V} / \mathrm{Al} 1060$ in the air using $\mathrm{Al}-12 \mathrm{Si}$ filler. In this study, ultrasonic vibration was applied to Ti-6Al-4V plate for $4 \mathrm{~s}$ at $620^{\circ} \mathrm{C}$ followed by 0,5 , 

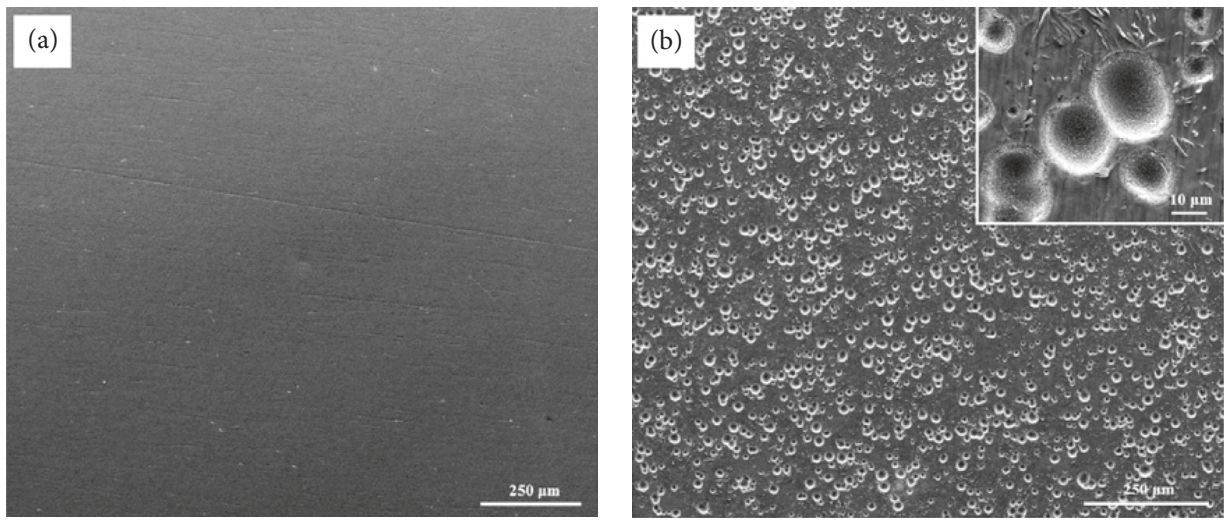

Figure 3: The morphology of Ti-6Al-4V substrate surface: (a) after interaction with the liquid Al-Si alloy for 10 min without ultrasonic treatment and (b) with ultrasonic treatment for $8 \mathrm{~s}$. Reproduced from Chen et al. [52], copyright 2012, with permission from Elsevier.
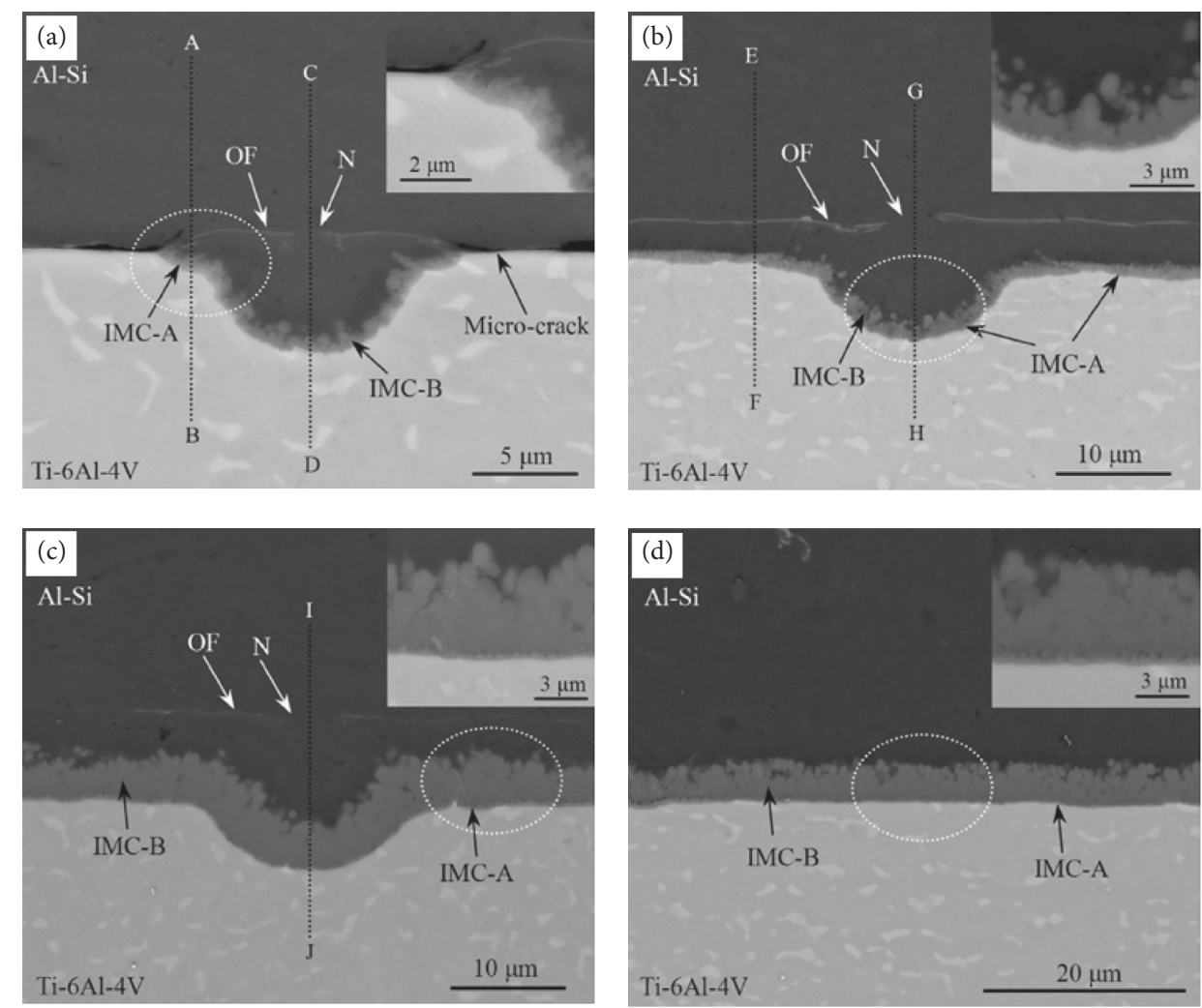

Figure 4: The microstructure (SEM) of Al-12Si/Ti-6Al-4V interface after: (a) $4 \mathrm{~s}$; (b) $4 \mathrm{~s}+5 \mathrm{~min}$; (c) $4 \mathrm{~s}+15 \mathrm{~min}$; (d) $4 \mathrm{~s}+15 \mathrm{~min}+4 \mathrm{~s}$. Reproduced from Chen et al. [39], copyright 2013, with permission from Elsevier.

and 15 min holding time, and then by a second ultrasonic vibration period for $4 \mathrm{~s}$. Applying the first ultrasonic vibration for $4 \mathrm{~s}$ caused formation of pits at the surface of the titanium alloy (Figure 4(a)). By applying a holding time of 5 or $15 \mathrm{~min}$, the dissolving continued at Al1060 and $\mathrm{Ti}$ sides; consequently, the oxide film detached off the titanium substrate which is called "substrate oxide undermining" (Figures 4(b) and 4(c)). In addition to the pit formation, the cavitation and the stirring action of acoustic streaming caused the following effects during the ultrasound operation: (i) Accelerating the dissolution process at $\mathrm{Ti}$ side once the pits had been formed on the Ti oxide film, as well as along Al1060 side.

(ii) During the second $4 \mathrm{~s}$ of USV, breaking the floating oxide film of the titanium alloy (Figure $4(\mathrm{~d})$ ). Simultaneously, breaking the $\mathrm{Al}$ dendrites and causing the $\mathrm{Al}$ phases to distribute uniformly in the joint.

Anyway, increasing holding time to $15 \mathrm{~min}$ or adding a second USV period did not improve the shear strength of the brazed joints. 

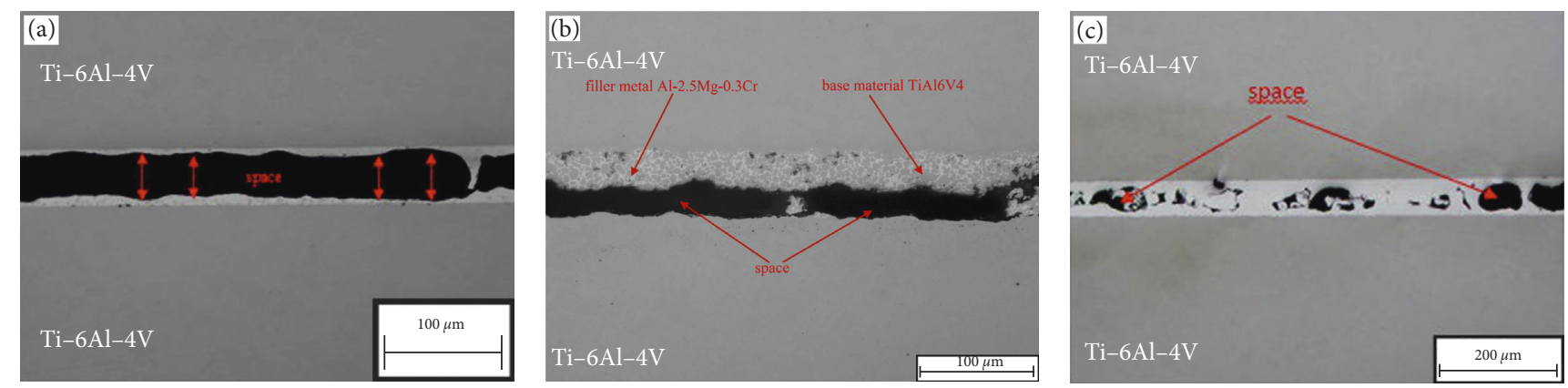

Figure 5: The formed voids and gaps in Ti-6 Al-4V/Al-2.5Mg-0.3Cr/Ti-6Al-4V brazed joints by different ultrasound-assisted brazing parameters: (a) $100 \mu \mathrm{m}, 670^{\circ} \mathrm{C}, 5 \mathrm{~s}, 60 \%$, (b) $60 \mu \mathrm{m}, 660^{\circ} \mathrm{C}, 5 \mathrm{~s}, 50 \%$, and (c) $100 \mu \mathrm{m}, 660^{\circ} \mathrm{C}, 5 \mathrm{~s}, 80 \%$. Reproduced from Tillmann et al. [37], copyright 2015, with permission from Springer.

Tillmann et al. [37] studied the ultrasound-assisted brazing of Ti-6Al-4V using $\mathrm{Al}-2.5 \mathrm{Mg}-0.3 \mathrm{Cr}$ filler and induction heating. The studied parameters were the layer thickness $(60-200 \mu \mathrm{m})$, brazing temperature $\left(660-680^{\circ} \mathrm{C}\right)$, and acoustic power (60-96 W), and then the sample of the best ultrasound-assisted brazing parameters was compared to a traditional vacuum brazing one. Increasing temperature over $660^{\circ} \mathrm{C}$ or reducing the thickness to less than $100 \mu \mathrm{m}$ resulted in big voids in the brazed area. Increasing the acoustic power up to $70 \%(84 \mathrm{~W})$ resulted in a considerable reduction of the oxide layer at the interface, and less intensities could not remove the oxide layer, while the highest one of $80 \%$ caused a significant cavitation leading to gap formation in the joint (Figure 5). The highest shear strength obtained using the sample of $100 \mu \mathrm{m}, 660^{\circ} \mathrm{C}, 5 \mathrm{~s}, 70 \%$ did not reach more than $60 \mathrm{MPa}$ and between 30 and $40 \mathrm{MPa}$ for vacuum-brazed samples.

The lower strength values for the samples brazed in the vacuum were attributed to the low heating rate which resulted in an excessive formation of a low-ductility intermetallic at the interface.

Elrefaey et al. [38] conducted a preliminary investigation of the microstructure and the fracture behavior of ultrasoundassisted brazing of Grade 2 titanium using $50 \mu \mathrm{m}$ TiBrazreAl$665 \mathrm{~A}(\mathrm{Al}-2.5 \mathrm{Mg}-0.3 \mathrm{Cr}$ ) filler alloy. The results showed the formation of the thin interaction layer of $\mathrm{Ti}_{3} \mathrm{Al}$, and the joint failed mainly at $\mathrm{Ti} / \mathrm{Al}$ interface due to the brittle nature of the intermetallic. Chen et al. [55] investigated the addition of $S n$ to $\mathrm{Al}-9.4 \mathrm{Si}-10 \mathrm{Zn}-10 \mathrm{Cu}-2 \mathrm{Ni}$ in ultrasound-assisted brazing of $\mathrm{Ti} / \mathrm{Al}$ joint. In a similar way in other works $[39,62,68]$, a simple overlap assembly was used with a preset joint clearance of $200 \mu \mathrm{m}$. The addition of $\mathrm{Sn}$ caused the widening of the melting range; before reaching the solidus temperature, the residual Snrich liquid filled the capillary gaps between the solidified $\mathrm{CuAl}_{2}$ grains which significantly reduced the residual thermal stresses and enhanced the joint strength [55].

To guarantee the efficient transfer of USV to the joint, the fixing rig and the mechanism by which the USV is being transferred should be designed carefully. This includes the consideration of the acoustic properties of the fixing rig components, the applied force on the joining area, and the location of the sonotrode tip [69]. Elrefaey et al. [38] used, for instance, an apparatus where the horn was installed

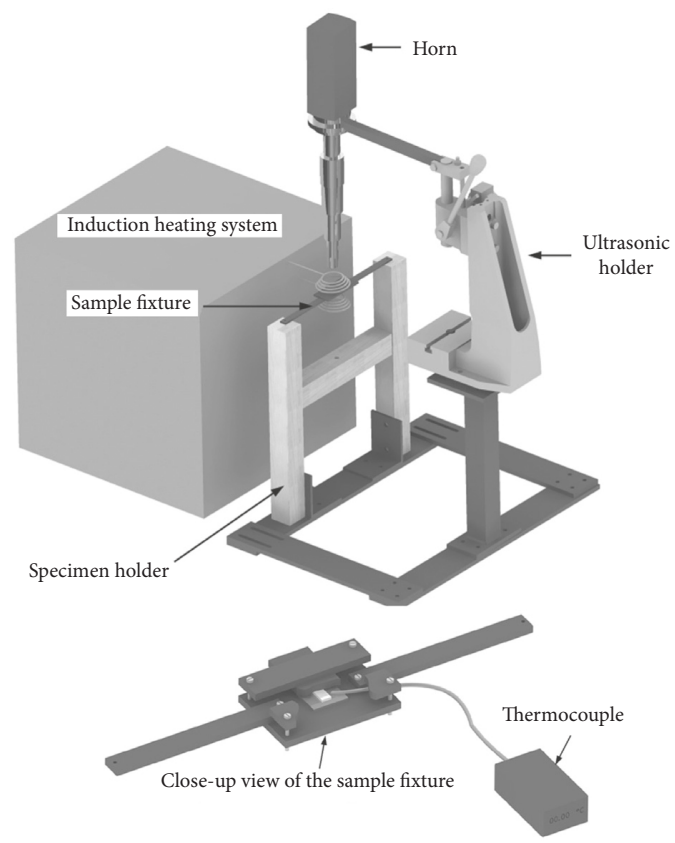

FIgURE 6: Schematic illustration of an ultrasonic-assisted brazing apparatus used by Elrefaey et al. Reproduced from Elrefaey et al. [38], copyright 2013, with permission from American Welding Society (AWS).

vertically, and the sample which was mounted into a steel holder was under 0.2 MPa pressure as a result of the horn weight (Figure 6). While, Tillmann et al. [37] used overlapped brazing joints with a torque of $8 \mathrm{Nm}$ introduced by a screw connection.

Even though using USV is a valuable way to break up the oxide layer and improve the properties of the joint, the results of ultrasound-assisted brazing of $\mathrm{Ti} / \mathrm{Ti}$ and $\mathrm{Ti} / \mathrm{Al}$ confirm that the process needs more control and investigation on the brazing conditions/materials to achieve higher mechanical properties.

2.2. The Intermetallic Compound Formation at the Ti/Al Interface. Several intermetallic phases occur in the $\mathrm{Ti}-\mathrm{Al}$ system such as $\alpha_{2}-\mathrm{Ti}_{3} \mathrm{Al}, \gamma-\mathrm{TiAl}, \mathrm{TiAl}_{3}, \mathrm{TiAl}_{2}$ and $\mathrm{Ti}_{2} \mathrm{Al}_{5}$ [70]. In fact, only $\mathrm{Ti}_{3} \mathrm{Al}$ and $\mathrm{TiAl}$ are technically interesting [71]. 
Since almost all filler metals form intermetallic compounds with titanium [29], therefore, studying and controlling their formation/development at the interface largely determine the mechanical behavior of the brazed joints. The formation and growth of the intermetallic compound at the interface is related basically to the compositions of the filler materials, the parent material, and the temperature-time parameters. Brazing titanium with pure aluminum, for instance, mainly leads to the formation of $\mathrm{TiAl}_{3}$ at the interface; adding $\mathrm{Si}$ $(\geq 3 \%)$ to the aluminum filler alloy will lead to formation of $\mathrm{Ti}_{7} \mathrm{Al}_{5} \mathrm{Si}_{12}$ and $\mathrm{Ti}_{9} \mathrm{Al}_{23}$; however, adding $\mathrm{Cu}$ or $\mathrm{Ag}$ will not change the probability of $\mathrm{TiAl}_{3}$ formation [29]. The predicted phase by the effective heat of the formation rule does not necessarily form at the moving reaction interface if it is difficult to nucleate [72]. Many studies showed that $\mathrm{TiAl}_{3}$ would form at the expense of the preexisting $\mathrm{Ti}_{3} \mathrm{Al}$ or $\mathrm{TiAl}$ phases in the presence of excess Al. Sujata et al. [73] calculated the free energies of formation of different titanium aluminide compounds in the temperature range $\sim\left(0-1200^{\circ} \mathrm{C}\right)$, and they found that the free energy of $\mathrm{TiAl}_{3}$ is less than that of $\mathrm{Ti}_{3} \mathrm{Al}$ and $\mathrm{TiAl}$ but slightly higher than that of $\mathrm{TiAl}_{2}$ and $\mathrm{Ti}_{2} \mathrm{Al}_{5}$. The preferred formation of $\mathrm{TiAl}_{3}$ as the only product during solid $\mathrm{Ti} /$ liquid $\mathrm{Al}$ reaction was explained by two factors: the first one is the additional steps in $\mathrm{TiAl}_{2}$ and $\mathrm{Ti}_{2} \mathrm{Al}_{5}$ formation which include $\mathrm{TiAl}$ as one of the starting phases and the second factor is the presence of the excess amount of liquid $\mathrm{Al}$ which minimizes the trend of TiAl or Ti-rich compound $\mathrm{Ti}_{3} \mathrm{Al}$ formation. Wöhlert and Bormann [74] investigated the phase selection mechanism of intermetallic compounds in $\mathrm{Ti} / \mathrm{Al}$ phase reaction. The predeposited layers of $\mathrm{Ti}_{3} \mathrm{Al}$ and $\mathrm{TiAl}$, between $\mathrm{Al} / \mathrm{Ti}$ elemental layers after annealing for 50 and $20 \mathrm{~h}$ at $400^{\circ} \mathrm{C}$, respectively, were disappeared and replaced by $\mathrm{TiAl}_{3}$. Accordingly, the phase selection during the interface reaction was explained by the differences in growth velocities of the competing phases. Similar main phase selection reason was concluded by Michaelsen et al. [75] including the nucleation as a first step in $\mathrm{TiAl}_{3}$ formation. Analogous results of $\mathrm{TiAl}_{3}$ formation on a $\mathrm{Ti}_{3} \mathrm{Al}$-based alloy were reported by Zhang et al. [76] by using hot dip aluminizing $\left(750^{\circ} \mathrm{C}-15 \mathrm{~s}\right)$ followed by interdiffusion treatment $\left(600^{\circ} \mathrm{C}-30 \mathrm{~h}\right)$. It was found that the addition of $\mathrm{Si}, \mathrm{Mn}$, or $\mathrm{Ag}$ to the pure $\mathrm{Al}$ coating improved the thickness uniformity and reduced the formation of the transverse cracks. Further intermediate layers consisting of $\left(\mathrm{TiAl}_{3}+\mathrm{TiAl}_{2}\right)$ and/or TiAl were formed after high-temperture oxidation for all the coatings. Zhang et al. [77] reported in another work using similar aluminizing and interdiffusion procedures the growth of $\mathrm{TiAl}_{2}$ and $\mathrm{TiAl}$, as solid state reaction products at the interface of $\mathrm{TiAl}_{3}$ and $\mathrm{Ti}-6 \mathrm{Al}-4 \mathrm{~V}$ substrate after the subsequent oxidation at $700^{\circ} \mathrm{C}$ and $300 \mathrm{~h}$, whereas $\mathrm{TiAl}_{3}+\mathrm{TiAl}_{2}$ and $\mathrm{Ti}_{3} \mathrm{Al}$ layers were formed at $800^{\circ} \mathrm{C}$ and $300 \mathrm{~h}$ of oxidation in air. The mixed $\mathrm{TiAl}_{3}+\mathrm{TiAl}_{2}$ layer resulted from $\mathrm{O}_{2}$ reaction with $\mathrm{TiAl}_{3}$. Xu et al. [78] applied vacuum hot pressing on $\mathrm{Ti} / \mathrm{Al}$ laminates followed by annealing and found that the next reaction phase after $\mathrm{TiAl}_{3}$ was $\mathrm{TiAl}$ at the $\mathrm{Ti} / \mathrm{Al}$ interface after consuming $\mathrm{Al}$ layer and during a second-stage annealing treatment at higher temperatures. The diffusion at the $\mathrm{Al} / \mathrm{Ti}$ interface can be accelerated with the amount of cold/hot rolling reduction $[78,79]$. In brazing titanium alloy OT4 by Mg-containing aluminum alloys, the formation of $\mathrm{TiAl}_{2}$ between $\mathrm{TiAl}_{3}$ and titanium also could take place [31].

The diffusion of the chemical elements across the interface of the brazing joint is high at the beginning of the brazing process since the diffusion at the beginning is between liquid and solid phases. As soon as the formation of the intermetallic compounds takes place, the diffusion rate is reduced and becomes less and less by increasing the intermetallic layer thickness until the growth of the intermetallic compound is suppressed. Considering, in titaniumrich aluminide, titanium can diffuse faster than $\mathrm{Al}[80,81]$. The thickness of the intermetallic layer when using pure aluminum as a filler is the largest one, and any addition or impurity elements will suppress-but differently-the growth of the intermetallic layer [29].

Brazing titanium aluminide TiAl at $900^{\circ} \mathrm{C}$ for $30 \mathrm{~s}$ using pure $\mathrm{Al}$ filler produced very weak joint, and the primary phase in the joint was the brittle $\mathrm{TiAl}_{3}$ phase [35]. On the other hand, for a different case with longer bonding cycle under pressure and without any additional filler, the "diffusion bonding" of two-phases gamma-based titanium aluminide $\mathrm{Ti}-45 \mathrm{Al}$ (in at.\%) produced $\alpha_{2}-\mathrm{Ti}_{3} \mathrm{Al}$ phase at the bonding interface. It was concluded by Buque and Appel [82] that the unavoidable contamination of the diffusion couple with oxygen leads to the formation of a thin layer of $\alpha_{2}-\mathrm{Ti}_{3} \mathrm{Al}$ phase. Similar result was found by Herrmann and Appel [83] for various two-phase gamma-based titanium aluminides, even considerably higher vacuum was used.

\subsection{Main Aluminum-Based Filler Systems}

2.3.1. Pure Aluminum as a Filler Metal. Pure aluminum is highly active with titanium at brazing temperature causing high erosion level, consequently, unreliable brazed joints specially for the thin-wall titanium structures [2]. Takemoto et al. [28, 29] found that the highest thickness of the intermetallic compound $\mathrm{TiAl}_{3}$ was caused by using pure aluminum as a filler. The small additions of alloying elements or impurities to the pure Al filler reduced the intermetallic layer thickness at the brazed interface. It was found that the addition of $0.8 \% \mathrm{Si}$ greatly reduced the thickness and the growth rate of the intermetallic $\mathrm{TiAl}_{3}$, and the produced $\mathrm{Ti} / \mathrm{Ti}$ joints using $\mathrm{Al}$ $0.8 \mathrm{Si}$ filler maintained higher joint strengths after brazing for relatively higher temperatures and longer holding times comparing with pure Al filler [29]. In the same context, Shiue et al. [35] found that the bonding strength of TiAl/Al/TiAl joint was very weak to be evaluated due to the extensive presence of the stable $\mathrm{TiAl}_{3}$ phase in the joint.

The minor modifications in the alloying elements affect the wetting and spreading behavior and should be designed according to the type of the Ti parent metal. For instance, comparing the fillers $\mathrm{Al}-4.5 \mathrm{Mg}-0.4 \mathrm{Si}-0.1 \mathrm{Cr}$ and $\mathrm{Al}-4 \mathrm{Mg}-$ $0.5 \mathrm{Si}-0.4 \mathrm{Mn}$ [30], the former with more $0.5 \% \mathrm{Mg}$ and $0.1 \mathrm{Cr}$ instead of $0.4 \mathrm{Mn}$, has a lower contact angle and better spreading on Grade 5 titanium; by contrast, these 
TABle 4: Ti/Ti-Ti/Al-brazed joints using pure or low-alloyed Al fillers.

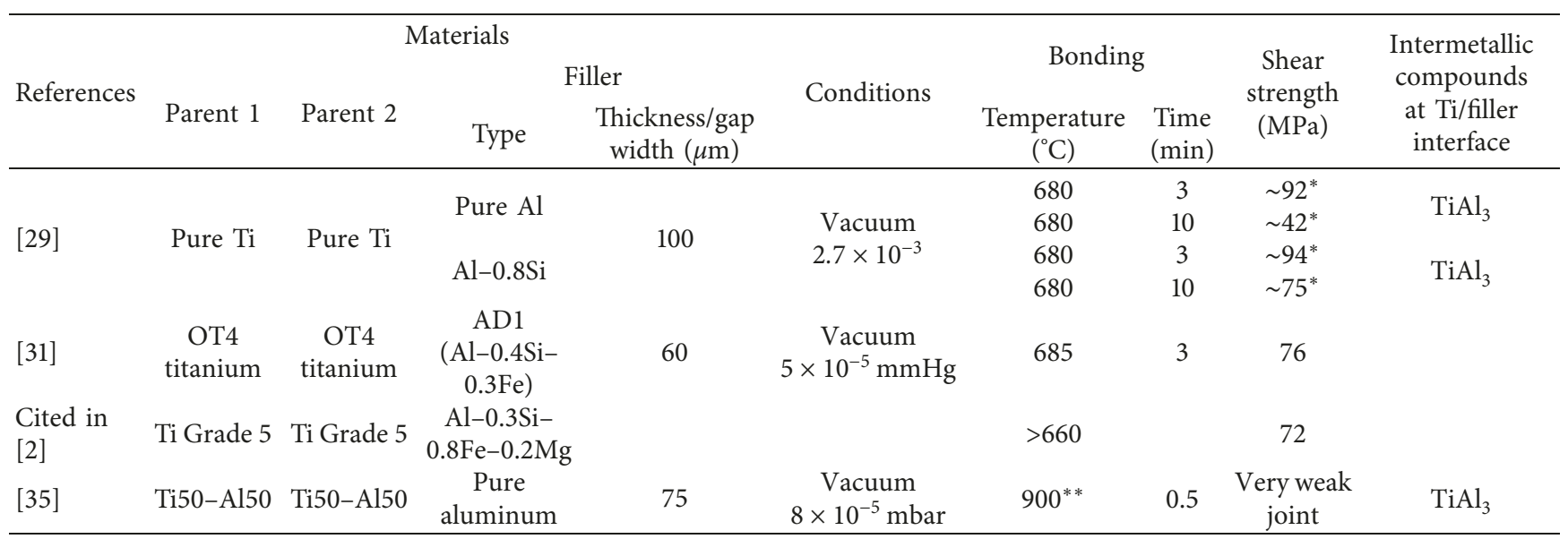

${ }^{*}$ The shear strength values calculated according to Figure 11 in [29]. ** Infrared brazing $900^{\circ} \mathrm{C} / \mathrm{min}$, preheating in $400^{\circ} \mathrm{C}$ for $60 \mathrm{~s}$.

modifications have a different effect in brazing Grade 2 titanium. Table 4 shows a summary of Ti/Ti-Ti/Al-brazed joints using pure or low-alloyed Al fillers.

2.3.2. Al-Mg-Type Filler Alloys. Flom [84] reported the disappearing of magnesium from the interface layer between $\mathrm{Al}-\mathrm{Mg}$ filler alloy and titanium parent alloy during vacuum brazing. Similarly, Khorunov et al. [31] found, after brazing using AMg6 alloy containing $6 \%$ of $\mathrm{Mg}$, that only $1.5 \%$ of $\mathrm{Mg}$ remained in the joint and no $\mathrm{Mg}$ remained at the interface; the reduction of $\mathrm{Mg}$ was explained by the evaporation of $\mathrm{Mg}$ from the filler during the heating and melting in vacuum. The volatility of magnesium in elevated temperatures [85] and the reaction of the magnesium vapor with the oxide surface of aluminum make $\mathrm{Mg}$ an excellent wetting promoter [86]. Mg reacts with aluminum oxide forming a complex oxide $\mathrm{MgAl}_{2} \mathrm{O}_{4}$ [87] or reducing it to $\mathrm{Al}+\mathrm{MgO}$ [34], which forms inclusions and induces bonding to occur; as a result, the content of $\mathrm{Mg}$ is reduced in the joint considerably [31]. The improved wetting of $\mathrm{Al}-\mathrm{Mg}$ filler alloys was also confirmed by Khorunov et al. [31], where Al-Mg filler showed better wetting on titanium alloy OT4 for a temperature less than $700^{\circ} \mathrm{C}$ comparing with $\mathrm{Al}-\mathrm{Si}$. Raising brazing temperature more than $700^{\circ} \mathrm{C}$ resulted in reducing the contact angle for all the fillers containing $\mathrm{Si}$ or $\mathrm{Mg} . \mathrm{Mg}$ content in the filler and the brazing conditions must be taken together into consideration when designing the brazing alloy, for example, $\mathrm{Al}-4 \mathrm{Mg}-0.5 \mathrm{Si}-0.4 \mathrm{Mn}$ alloy showed a good result of $117 \mathrm{MPa}$ in torch brazing but produced only $61 \mathrm{MPa}$ in vacuum brazing [30]. Another example, the vacuum brazing by $\mathrm{Mg}$-containing filler alloys of $6 \%$ and $2.5 \% \mathrm{Mg}$ showed almost identical strengths which were higher than the one using the Si-containing fillers [31]. Eckardt et al. [30] reported the formation of a variable and discontinuous intermetallic layer of $\mathrm{TiAl}_{3}$ between the $\mathrm{Al}-\mathrm{Mg}$ fillers and the titanium parent metal. In addition, it was reported that a thicker intermetallic layer was formed on Grade 5 titanium comparing with Grade 2 titanium. The high-Mg alloys did not show better fillet formation properties compared with the average-Mg braze alloy such as
TiBraze 665 which contains only $2.5 \%$ Mg [30]. Table 5 shows a summary of Ti/Ti-Ti/Al-brazed joints using Al-Mgtype filler alloys.

2.3.3. Al-Si-Type Filler Alloys. Takemoto and Okamoto [29] reported that the small addition of $0.2-0.8 \% \mathrm{Si}$ is highly effective in suppressing the intermetallic layer growth of $\mathrm{TiAl}_{3}$. However, further additions $\geq 3 \%$ of $\mathrm{Si}$ increased the intermetallic thickness and promoted the formation of additional intermetallic compounds: $\mathrm{Ti}_{9} \mathrm{Al}_{23}$ and $\mathrm{Ti}_{7} \mathrm{Al}_{5} \mathrm{Si}_{12}$ at the interface, where $\mathrm{Ti}_{7} \mathrm{Al}_{5} \mathrm{Si}_{12}$ was adjacent to the titanium parent side. Using $\mathrm{Al}-10 \mathrm{Si}-1 \mathrm{Mg}$ mainly produced $\mathrm{Ti}_{7} \mathrm{Al}_{5} \mathrm{Si}_{12}$ and a small quantity of $\mathrm{Ti}_{9} \mathrm{Al}_{23}$ intermetallic compounds. The best result of tensile test was for $\mathrm{Al}-10 \mathrm{Si}-1 \mathrm{Mg}$ comparing with the other two filler materials $\mathrm{Al}-10 \mathrm{Cu}-8 \mathrm{Sn}$ and $\mathrm{Al}-30 \mathrm{Ag}-10 \mathrm{Cu}$. It was found that the fracture occurred within the filler metal when using Al-10Si-1Mg [29]. Under almost similar conditions, but for longer brazing time, Sohn et al. [34] investigated the diffusion brazing of $\mathrm{Al} / \mathrm{Ti}$ joint by $\mathrm{Al}-10 \mathrm{Si}-1 \mathrm{Mg}$. The bonding at the $\mathrm{Ti} /$ filler interface started as soon as the filler had been melted; two intermetallic compounds were observed, the continuous $\mathrm{Ti}_{7} \mathrm{Al}_{5} \mathrm{Si}_{12}$ at the titanium side, which increased by the time due to the diffusion of $\mathrm{Si}$ into $\mathrm{Ti}$, and the discontinuous one $\mathrm{Ti}_{5} \mathrm{Al}_{12} \mathrm{Si}_{3}$ at the filler side and the fracture occurred in $\mathrm{Al}$ layer. In ultrasound brazing of titanium, two intermetallic compounds $\mathrm{Ti}_{9} \mathrm{Al}_{23}$ and $\mathrm{Ti}_{7} \mathrm{Al}_{5} \mathrm{Si}_{12}$ were formed at Ti-6Al-4V/Al-12Si filler interface [39]. The intermetallic IMC-A $\left(\mathrm{Ti}_{7} \mathrm{Al}_{5} \mathrm{Si}_{12}\right)$ formed at the pit edge during the first USV, while IMC-B $\left(\mathrm{Ti}_{9} \mathrm{Al}_{23}\right)$ at the wall and the bottom of the pit. Applying holding time for 5 min caused the IMC-A $\left(\mathrm{Ti}_{7} \mathrm{Al}_{5} \mathrm{Si}_{12}\right)$ to form at the interface between IMC-B $\left(\mathrm{Ti}_{9} \mathrm{Al}_{23}\right)$ and $\mathrm{Ti}-6 \mathrm{Al}-4 \mathrm{~V}$; by increasing the holding time to $15 \mathrm{~min}$, the thickness of IMC-B $\left(\mathrm{Ti}_{9} \mathrm{Al}_{23}\right)$ increased (Figure 4). Wells [41] reported that the $\mathrm{Al}-7.5 \% \mathrm{Si}$ alloy cladded to a core of aluminum alloy 6951, which did not melt during brazing, produced stronger joint than $63 \mathrm{Al}-32 \mathrm{Cu}-5 \mathrm{Ag}-0.01 \mathrm{Li}$ for Grade $5 \mathrm{Ti}$. However, Khorunov et al. [31] found that Mg-containing filler alloys provided higher joint strength than the Si-containing filler alloy $(5.3 \% \mathrm{Si})$, which was explained by the solidification of the silicide 


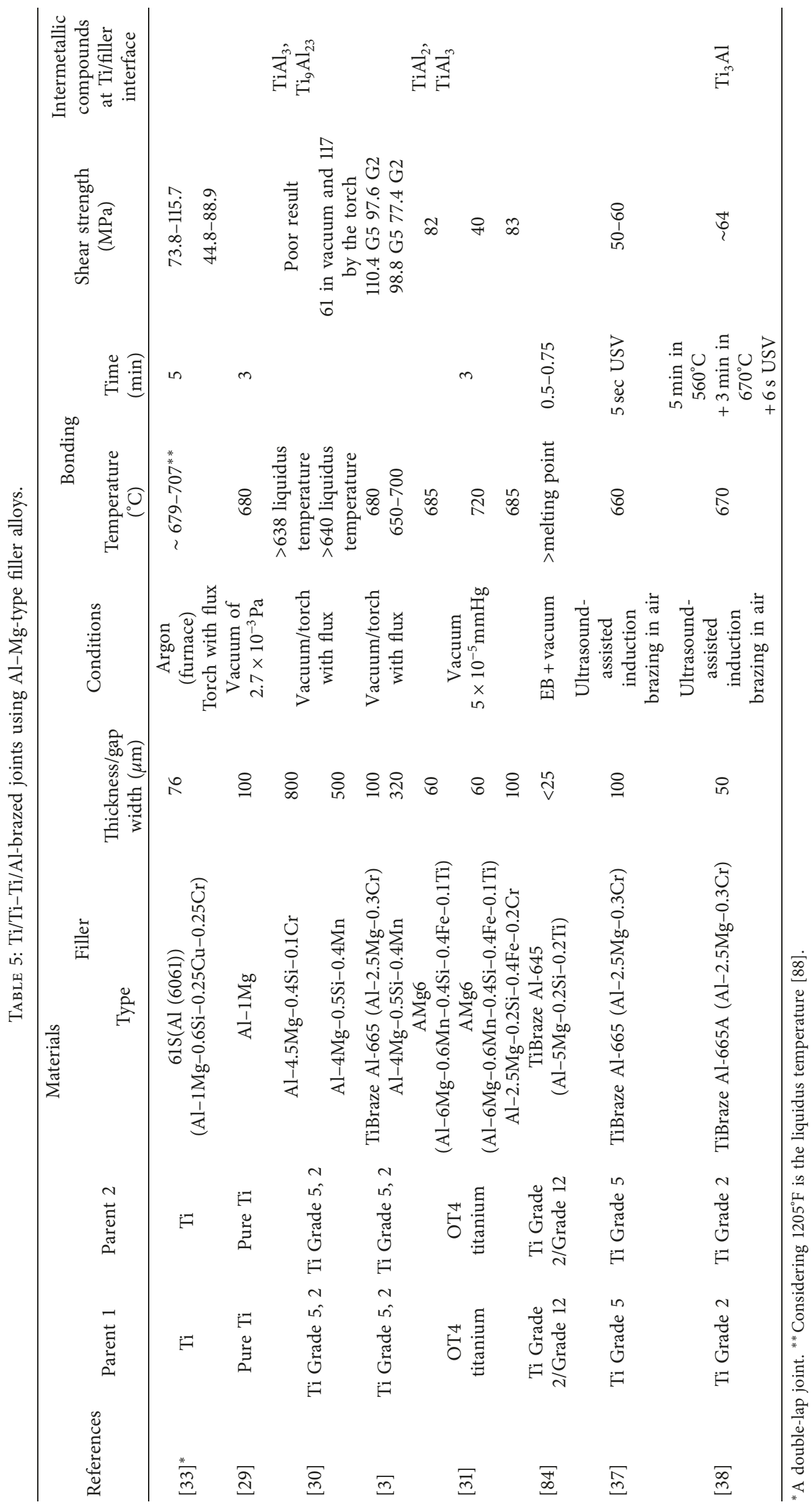




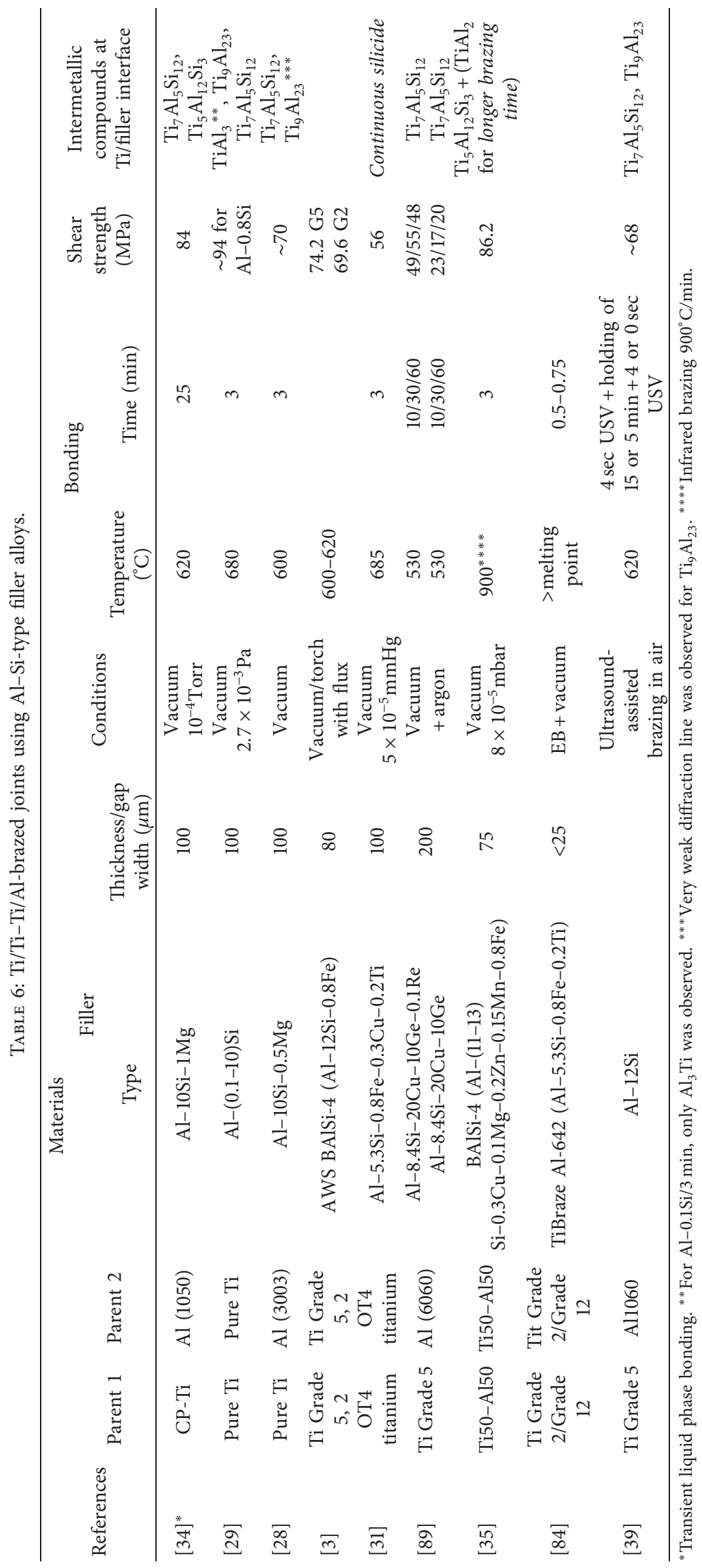




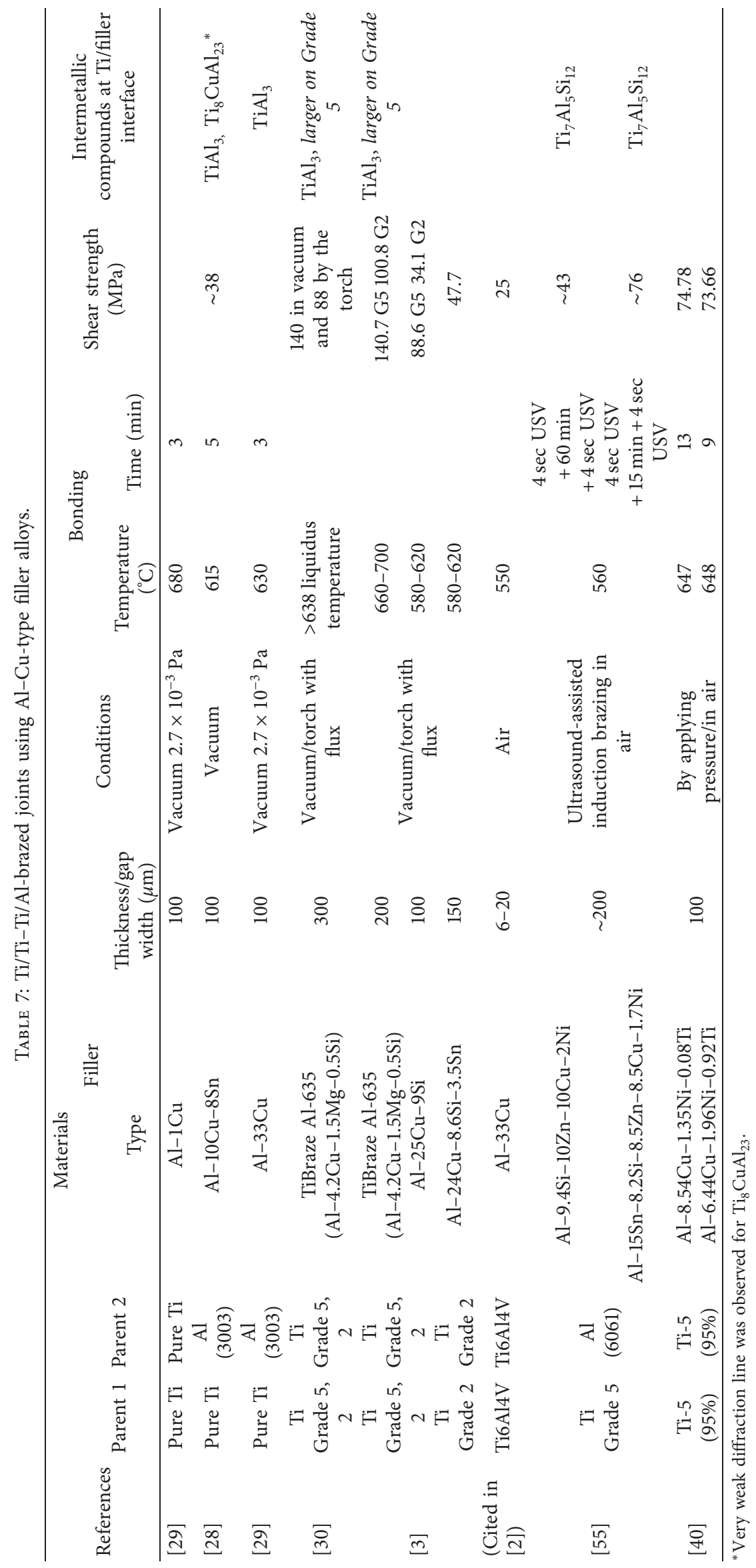


TABle 8: Ti/Ti-Ti/Al-brazed joints using Al-Ag-type filler alloys.

\begin{tabular}{|c|c|c|c|c|c|c|c|c|c|}
\hline \multirow{3}{*}{ References } & \multirow{3}{*}{$\begin{array}{c}\text { Parent } \\
1\end{array}$} & \multirow{3}{*}{$\begin{array}{c}\text { Parent } \\
2\end{array}$} & \multicolumn{2}{|c|}{ Materials } & \multirow{3}{*}{ Conditions } & \multirow{2}{*}{\multicolumn{2}{|c|}{ Bonding }} & \multirow{3}{*}{$\begin{array}{l}\text { Shear } \\
\text { strength } \\
\text { (MPa) }\end{array}$} & \multirow{3}{*}{$\begin{array}{c}\text { Intermetallic } \\
\text { compounds at } \\
\text { Ti/filler interface }\end{array}$} \\
\hline & & & \multicolumn{2}{|c|}{ Filler } & & & & & \\
\hline & & & Type & $\begin{array}{l}\text { Thickness/gap } \\
\text { width }(\mu \mathrm{m})\end{array}$ & & $\begin{array}{c}\text { Temperature } \\
\left({ }^{\circ} \mathrm{C}\right)\end{array}$ & $\begin{array}{l}\text { Time } \\
\text { (min) }\end{array}$ & & \\
\hline [28] & Pure Ti & $\begin{array}{c}\mathrm{Al} \\
(3003)\end{array}$ & $\mathrm{Al}-20 \mathrm{Ag}-10 \mathrm{Cu}$ & 100 & Vacuum & 600 & 5 & $\sim 38$ & $\mathrm{TiAl}_{3}$ \\
\hline [29] & Pure Ti & $\begin{array}{c}\mathrm{Al} \\
(3003)\end{array}$ & A1-33Ag & 100 & $\begin{array}{c}\text { Vacuum } \\
2.7 \times 10^{-3} \mathrm{~Pa}\end{array}$ & 630 & 3 & & $\mathrm{TiAl}_{3}$ \\
\hline$[30]$ & $\begin{array}{c}\mathrm{Ti} \\
\text { Grade } \\
5,2\end{array}$ & $\begin{array}{c}\mathrm{Ti} \\
\text { Grade } \\
5,2\end{array}$ & $\begin{array}{l}\mathrm{Al}-38 \mathrm{Ag}- \\
7.4 \mathrm{Si}-0.6 \mathrm{Fe}\end{array}$ & 260 & $\begin{array}{l}\text { Vacuum/torch } \\
\text { with flux }\end{array}$ & $\begin{array}{c}>580 \text { liquidus } \\
\text { temperature }\end{array}$ & & $\begin{array}{l}\text { Poor } \\
\text { result }\end{array}$ & $\mathrm{Ti}_{7} \mathrm{Al}_{5} \mathrm{Si}_{12}{ }^{* *}$ \\
\hline [3] & $\begin{array}{c}\mathrm{Ti} \\
\text { Grade }\end{array}$ & $\begin{array}{c}\mathrm{Ti} \\
\text { Grade }\end{array}$ & $\mathrm{Al}-28 \mathrm{Ag}$ & $\begin{array}{l}\text { Powder } \\
+325 /-100 \\
\text { mesh }\end{array}$ & Vacuum/torch & $600-620$ & & 70 & \\
\hline & 2 & 2 & $\begin{array}{l}\mathrm{Al}-28.5 \mathrm{Ag}- \\
21 \mathrm{Cu}-1.3 \mathrm{Mg}\end{array}$ & 260 & & $650-710$ & & 67.6 & \\
\hline
\end{tabular}

${ }^{* *}$ Another undetermined very thin one.

TABle 9: Ti/Ti-brazed joints using Al-Ni- and Al-Mn-type filler alloys.

\begin{tabular}{|c|c|c|c|c|c|c|c|c|c|}
\hline \multirow[b]{2}{*}{ References } & \multirow[b]{2}{*}{$\begin{array}{c}\text { Parent } \\
1\end{array}$} & \multirow[b]{2}{*}{$\begin{array}{c}\text { Parent } \\
2\end{array}$} & Materials & & \multirow[b]{2}{*}{ Conditions } & \multicolumn{2}{|c|}{ Bonding } & \multirow{2}{*}{$\begin{array}{l}\text { Shear } \\
\text { strength } \\
(\mathrm{MPa})\end{array}$} & \multirow{2}{*}{$\begin{array}{c}\text { Intermetallic } \\
\text { compounds } \\
\text { at Ti/filler } \\
\text { interface }\end{array}$} \\
\hline & & & Type & $\begin{array}{l}\text { Thickness/gap } \\
\text { width }(\mu \mathrm{m})\end{array}$ & & $\begin{array}{c}\text { Temperature } \\
\left({ }^{\circ} \mathrm{C}\right)\end{array}$ & $\begin{array}{l}\text { Time } \\
(\mathrm{min})\end{array}$ & & \\
\hline [29] & Pure Ti & Pure Ti & $\mathrm{Al}-1 \mathrm{Mn}, \mathrm{Al}-1 \mathrm{Ni}$ & 100 & $\begin{array}{c}\text { Vacuum } \\
2.7 \times 10^{-3} \mathrm{~Pa}\end{array}$ & 680 & 3 & & \\
\hline [30] & $\begin{array}{c}\mathrm{Ti} \\
\text { Grade } \\
5,2\end{array}$ & $\begin{array}{c}\mathrm{Ti} \\
\text { Grade } \\
5,2\end{array}$ & $\begin{array}{c}\text { TiBraze Al-700 } \\
(\mathrm{Al}-21.5 \mathrm{Ni}-9 \mathrm{Cu}- \\
9.6 \mathrm{Si}-1.3 \mathrm{Fe}-0.6 \mathrm{Mn})\end{array}$ & 300 & $\begin{array}{l}\text { Vacuum/torch } \\
\text { with flux }\end{array}$ & $\geq 607$ & & $\begin{array}{c}93 \text { in } \\
\text { vacuum and } \\
\text { poor result } \\
\text { by torch }\end{array}$ & $\begin{array}{c}\mathrm{Ti}_{9} \mathrm{Al}_{23} \\
\mathrm{Ti}_{7} \mathrm{Al}_{5} \mathrm{Si}_{12}\end{array}$ \\
\hline [3] & $\begin{array}{c}\mathrm{Ti} \\
\text { Grade } \\
5,2\end{array}$ & $\begin{array}{c}\mathrm{Ti} \\
\text { Grade } \\
5,2\end{array}$ & $\begin{array}{c}\text { TiBraze Al-700 } \\
(\mathrm{Al}-21.5 \mathrm{Ni}-9 \mathrm{Cu}-9.6 \mathrm{Si})\end{array}$ & 290 & $\begin{array}{l}\text { Vacuum/torch } \\
\text { with flux }\end{array}$ & $700-720$ & & $\begin{array}{c}127.3 \mathrm{G} 5 \\
81.6 \mathrm{G} 2\end{array}$ & $\begin{array}{c}\mathrm{Ti}_{9} \mathrm{Al}_{23} \\
\mathrm{Ti}_{7} \mathrm{Al}_{5} \mathrm{Si}_{12}\end{array}$ \\
\hline $\begin{array}{l}\text { Cited in } \\
{[2]}\end{array}$ & $\begin{array}{l}\mathrm{Ti} \\
\text { Grade } \\
5\end{array}$ & $\begin{array}{l}\mathrm{Ti} \\
\text { Grade } \\
5\end{array}$ & $\begin{array}{c}\mathrm{Al}-1.2 \mathrm{Mn}-0.6 \mathrm{Si}-0.7 \mathrm{Fe}- \\
0.2 \mathrm{Cu}\end{array}$ & & & $>660$ & & 89 & \\
\hline
\end{tabular}

as a continuous strip at the brazing interface. Table 6 shows a summary of Ti/Ti-Ti/Al brazed joints using Al-Si-type filler alloys.

2.3.4. Al-Cu- and Al-Ag-Type Filler Alloys. Al-Cu and Al-Ag promoted mainly $\mathrm{TiAl}_{3}$ formation at the brazed interface of titanium. Adding $\mathrm{Sn}$ did not change the intermetallic type since $\mathrm{Al}-10 \mathrm{Cu}-8 \mathrm{Sn}$ filler metal mainly promoted $\mathrm{TiAl}_{3}$ formation in $\mathrm{Al}(\mathrm{A} 1100) / \mathrm{Ti}$ joints and very weak diffraction line corresponding to $\mathrm{Ti}_{8} \mathrm{CuAl}_{23}$. However, high peak of $\mathrm{Sn}$ at the interface was showed by EDX line analysis, and the fracture occurred within the intermetallic compound [29]. In a different manner, the existence of Si in the filler changes the intermetallic type; Chen et al. [55] reported the formation of the intermetallic $\mathrm{Ti}_{7} \mathrm{Al}_{5} \mathrm{Si}_{12}$ at the interface between the Grade $5 \mathrm{Ti}$ and each of Al-9.4Si$10 \mathrm{Zn}-10 \mathrm{Cu}-2 \mathrm{Ni}$ and $\mathrm{Al}-15 \mathrm{Sn}-8.2 \mathrm{Si}-8.5 \mathrm{Zn}-8.5 \mathrm{Cu}-1.7 \mathrm{Ni}$ fillers; it was concluded that the addition of Sn improved the strength through reducing the residual thermal stress.
Eckardt et al. [30] found that the filler alloy TiBraze Al-635 (Al-4.2Cu-1.5Mg-0.5Mn-0.5Si) had the lowest contact angle on Grade $5 \mathrm{Ti}$ and a good one (second-lowest one) on Grade $2 \mathrm{Ti}$ with the highest strength among the other alloys of $\mathrm{Al}-\mathrm{Ag}, \mathrm{Al}-\mathrm{Mg}$, and $\mathrm{Ag}-\mathrm{Cu}-\mathrm{Zn}-(\mathrm{Cd}-\mathrm{Sn})$ using vacuum brazing. The interlayer between the parent metal and the filler TiBraze Al-635 consisted of variable and discontinuous layer of $\mathrm{TiAl}_{3}$. According to Wells [41], the addition of $\mathrm{Mg}$ or the small addition of $\mathrm{Li}$ to the filler metal improved the flow characteristics of $\mathrm{Al}-\mathrm{Cu}-(5-50) \mathrm{Ag}$-type alloys; on the other hand, alloying with $\mathrm{Mg}$ significantly decreased the corrosion resistance of the joints. Si and/or Sn-containing filler metals formed weaker joints or exhibited flow temperature of $\sim 587^{\circ} \mathrm{C}(860 \mathrm{~K})$ or higher. It was found that the flow temperature for the $\mathrm{Al}-\mathrm{Cu}-\mathrm{Ag}$ alloys varied with the employed atmosphere; flow temperatures were $111^{\circ} \mathrm{C}$ higher in the vacuum than in $6.6 \times 10^{4} \mathrm{~Pa}$ of argon. In brazing damagetolerant titanium structures, $\mathrm{Al}-\mathrm{Cu}-\mathrm{Ag}$ filler materials prevent the cracks from spreading by delamination in the crack arrest orientation. The behavior in the crack divider 
orientation was similar to the behavior of the monolithic material [41]. Tables 7 and 8 show a summary of Ti/Ti-Ti/Albrazed joints using $\mathrm{Al}-\mathrm{Cu}$ and $\mathrm{Al}-\mathrm{Ag}$-type filler alloys, respectively.

2.3.5. Al-Ni, Al-Mn, and Other Types of Filler Alloys. Nickel addition to the pure aluminum filler had a little effect on the suppression of the intermetallic layer at the Ti/filler interface, whereas Mn addition showed a better result [29]. However, nickel addition to $\mathrm{Al}-\mathrm{Cu}-\mathrm{Ti}$ filler together with a decrease in copper ratio increased the shear strength [40]. Ge improved the corrosion resistance when added to the $\mathrm{Al}-\mathrm{Cu}$ - and $\mathrm{Al}-\mathrm{Cu}-\mathrm{Ag}$-type alloys but formed very fragile joints [41]. Table 9 shows a summary of Ti/Tibrazed joints using $\mathrm{Al}-\mathrm{Ni}$ - and $\mathrm{Al}-\mathrm{Mn}$-type filler alloys.

\section{Conclusions and Future Work}

In this review, the aluminum-based filler alloys for brazing titanium and the formation of the intermetallic compounds at the interface of $\mathrm{Ti} /$ filler have been analyzed. The proper design of time-temperature cycle and the controlled alloying additions in the aluminum filler are crucial factors for the intermetallic compound formation at the interface. The thickness and type of the intermetallic phases will largely determine the mechanical properties of the brazed joint. In the case of brazing Ti/Al joints, further decrease in brazing temperature, adequate time-temperature cycle, and the compatibility of the brazing filler on the both $\mathrm{Ti} / \mathrm{Al}$ sides should be considered thoroughly.

Several technological parameters have been examined for ultrasound-assisted brazing of titanium by Al-based filler alloys, including the acoustic power, the USV period, the holding time, the filler thickness, and the brazing temperature; accordingly, the following points should be highlighted:

(i) The holding time after USV is necessary for the diffusion process proceeding at the interface between the filler and the titanium parent metal.

(ii) Varying the power of the ultrasound affects the oxide removal at the filler/parent metal interface directly.

(iii) The thickness of the filler should be chosen according to USV parameters and time-temperature brazing cycle; considering the accelerated interaction between the liquid filler and the parent metal by the effect of USV.

(iv) Brazing and ultrasound parameters/conditions should be considered together in ultrasoundassisted brazing process, for instance, the ultrasonic power/intensity, the coupling method of the ultrasound with the workpiece which insures the excellent delivery of the USV to the joint area, the USV activation time, and other traditional brazing parameters.

(v) Studying the USV effects on the microstructure of the brazed joint should be given more attention.
Brazing process has many factors that should be considered to achieve the best possible mechanical properties of the produced joint; the quality of the filler material is one of these factors. Different processes are available for aluminum filler production; the casting process is used as a favorite way to produce new filler aluminum alloys or known ones of labscale size for testing purposes. However, the properties and the quality of the cast affect the mechanical properties and the quality of the final brazing joint. The impact of the cast defects and the imperfections varied according to the form of the brazing filler alloy and the brazing process. The filler alloy, as a primary consideration, should have homogeneous chemical composition, with controlled or free of inclusions, and free of porosity. Using USV in the preparation and developing specific, low-melting temperature filler alloys for brazing process from their pure elements would be a great tool in enhancing the filler alloy properties, accelerating the process, and thus, exploring more compatible brazing fillers. Due to the limited works in ultrasound-assisted brazing of Ti by Albased fillers and the mechanical properties of the produced joints, it is tempting to investigate and seeking to develop further compositions of the Al-based fillers which can be more adequate for ultrasound-assisted brazing of $\mathrm{Ti}$ and to conduct deeper studies considering the integration between the USV and the traditional brazing parameters.

\section{Conflicts of Interest}

The authors declare that they have no conflicts of interest.

\section{Acknowledgments}

This work is supported by Erasmus Mundus through PEACE II Lot 2 Project 2013-2443/001-001-EMA2 and FCT with the reference project UID/EEA/04436/2013, COMPETE 2020, with the code POCI-01-0145-FEDER-006941.

\section{References}

[1] T. Onzawa, A. Suzumura, and M. Ko, "Brazing of titanium using low-melting-point Ti-based filler metals," Welding Journal, vol. 462, 1990.

[2] A. E. Shapiro and Y. A. Flom, "Brazing of titanium at temperatures below $800^{\circ} \mathrm{C}$ : review and prospective applications," DVS Berichte, vol. 243, p. 254, 2007.

[3] A. E. Shapiro and Y. A. Flom, "New aluminum-based coldrolled and composite braze foils for brazing titanium below $700^{\circ} \mathrm{C}$," in Proceeding of the 5th International Brazing and Soldering Conference, pp. 427-432, Las Vegas, NV, USA, April 2012.

[4] M. J. Donachie, Titanium: A Technical Guide, ASM International, Materials Park, OH, USA, 2000.

[5] E. Gemelli and N. H. A. Camargo, "Oxidation kinetics of commercially pure titanium," Matéria (Rio de Janeiro), vol. 12, no. 3, pp. 525-531, 2007.

[6] F. H. Froes and I. L. Caplan, Titanium'92, Science and Technology: Proceedings of a Symposium Sponsored by the Titanium Committee of the Minerals Metals \& Materials, Structural Metals Division, Minerals, Metals and Materials Society, San Diego, CA, USA, 1993. 
[7] F. C. Campbell, Manufacturing Technology for Aerospace Structural Materials, pp. 119-174, Elsevier, Amsterdam, Netherlands, 2011.

[8] V. V. Voronov, "Development of the technology for brazing of titanium alloys using filler alloys based on the Al-Mg system," Paton Welding Journal, vol. 2013, no. 2, pp. 56-58, 2013.

[9] X. Huang and N. L. Richards, "Activated diffusion brazing technology for manufacture of titanium honeycomb structures-a statistical study," Welding Journal, vol. 83, no. 3, pp. 73-81, 2004.

[10] A. B. Kolomenskii, V. A. Salikov, A. N. Roshchupkin, and A. V. Degtyarev, "Efficiency of titanium honeycomb packets produced by diffusion bonding," Welding International, vol. 9, no. 9, pp. 742-744, 1995.

[11] D. P. Sekulić, Advances in Brazing: Science, Technology and Applications, Elsevier Science, Amsterdam, Netherlands, 2013.

[12] C. E. Smeltzer, J. F. Nachman, and A. N. Hammer, Titanium Braze System for High Temperature Applications, AFMLTR.76-145, Solar Division of International Harvester, San Diego, CA, USA, 1976.

[13] R. R. Boyer, "An overview on the use of titanium in the aerospace industry," Materials Science and Engineering: A, vol. 213, no. 1-2, pp. 103-114, 1996.

[14] K. Matsu, Y. Miyazawa, Y. Nishi, and T. Ariga, "Brazing and interfacial reaction of commercially pure titanium with Ti-Zrbased filler metals," Materials Transactions, vol. 48, no. 5, pp. 1055-1059, 2007.

[15] E. Ganjeh and H. Sarkhosh, "Microstructural, mechanical and fractographical study of titanium-CP and Ti-6Al-4V similar brazing with Ti-based filler," Materials Science and Engineering: A, vol. 559, pp. 119-129, 2013.

[16] E. Ganjeh, H. Sarkhosh, M. E. Bajgholi, H. Khorsand, and M. Ghaffari, "Increasing Ti-6Al-4V brazed joint strength equal to the base metal by Ti and Zr amorphous filler alloys," Materials Characterization, vol. 71, pp. 31-40, 2012.

[17] C. T. Chang, Y. C. Du, R. K. Shiue, and C. S. Chang, "Infrared brazing of high-strength titanium alloys by $\mathrm{Ti}-15 \mathrm{Cu}-15 \mathrm{Ni}$ and Ti-15Cu-25Ni filler foils," Materials Science and Engineering: A, vol. 420, no. 1-2, pp. 155-164, 2006.

[18] T. Onzawa and T. Iiyama, "Development of titanium-based brazing filler metals with low-melting-point," International Journal of Korean Welding Society, vol. 2, no. 2, pp. 14-18, 2002.

[19] Titanium Brazing, Inc., Products and Services, November 2017, http://www.titanium-brazing.com/products.html\#3.

[20] C. T. Chang, R. K. Shiue, and C. S. Chang, "Microstructural evolution of infrared brazed Ti-15-3 alloy using Ti-15Cu-15Ni and Ti-15Cu-25Ni fillers," Scripta Materialia, vol. 54, no. 5, pp. 853-858, 2006.

[21] R. K. Shiue, S. K. Wu, Y. T. Chen, and C. Y. Shiue, "Infrared brazing of Ti50Al50 and Ti-6Al-4V using two Ti-based filler metals," Intermetallics, vol. 16, no. 9, pp. 1083-1089, 2008.

[22] M. K. Lee and J. G. Lee, "Mechanical and corrosion properties of Ti-6Al-4V alloy joints brazed with a low-melting-point 62.7Zr-11.0Ti-13.2Cu-9.8Ni-3.3Be amorphous filler metal," Materials Characterization, vol. 81, pp. 19-27, 2013.

[23] M. K. Lee, K. H. Kim, J. G. Lee, and C. K. Rhee, "Growth of isothermally-solidified titanium joints using a multi-component $\mathrm{Zr}-\mathrm{Ti}-\mathrm{Cu}-\mathrm{Ni}-\mathrm{Be}$ amorphous alloy as a brazing filler," Materials Characterization, vol. 80, pp. 98-104, 2013.

[24] Ti-Flo Filler Metal for Titanium-Johnson Matthey Metal Joining Company, July 2017, http://www.jm-metaljoining. com/products/ti-flo.
[25] K. B. Pressly, J. A. Brunk, K. Gentry, E. Jimenez, E. M. Lundgren, and G. E. Parkhurst, Brazing Titanium Structures, BDX-613-1666(Rev.), National Technical Information Service, Springfield, VA, USA, 1977.

[26] Y. C. Du and R. K. Shiue, "Infrared brazing of Ti-6Al-4V using two silver-based braze alloys," Journal of Materials Processing Technology, vol. 209, no. 11, pp. 5161-5166, 2009.

[27] E. Ganjeh, H. Sarkhosh, H. Khorsand, H. Sabet, E. H. Dehkordi, and M. Ghaffari, "Evaluate of braze joint strength and microstructure characterize of titanium-CP with Ag-based filler alloy," Materials \& Design, vol. 39, pp. 33-41, 2012.

[28] T. Takemoto, H. Nakamura, and I. Okamoto, "Strength of titanium joints brazed with aluminum filler metals," Transactions of JWRI, vol. 19, no. 1, pp. 45-49, 1990.

[29] T. Takemoto and I. Okamoto, "Intermetallic compounds formed during brazing of titanium with aluminium filler metals," Journal of Materials Science, vol. 23, no. 4, pp. 1301-1308, 1988.

[30] T. Eckardt, B. Hanhold, D. Petrasek, S. Sattler, A. Benatar, and A. Shapiro, "Evaluating low-temperature brazing filler metals for joining titanium," Welding Journal, vol. 91, no. 2, pp. 45-50, 2012.

[31] V. F. Khorunov, V. V. Voronov, and S. V. Maksymova, "Brazing of titanium alloys by using aluminium-base filler alloys," Paton Welding Journal, vol. 11, pp. 2-5, 2012.

[32] A. E. Shapiro and E. Y. Ivanov, "Heat-resistant brazing filler metals for joining titanium aluminide and titanium alloys," in Proceedings of the 3rd International Brazing and Soldering Conference (IBSC), pp. 12-17, San Antonio, TX, USA, 2006.

[33] W. J. Lewis, P. S. Rieippel, and C. B. Voldrich, Brazing Titanium to Titanium and to Mild and Stainless Steels, Part 1, Tech. Rep. 52-313, Battelle Memorial Institute, Columbus, OH, USA, 1952.

[34] W. H. Sohn, H. H. Bong, and S. H. Hong, "Microstructure and bonding mechanism of $\mathrm{Al} / \mathrm{Ti}$ bonded joint using $\mathrm{Al}-10 \mathrm{Si}-$ $1 \mathrm{Mg}$ filler metal," Materials Science and Engineering: A, vol. 355, no. 1-2, pp. 231-240, 2003.

[35] R. K. Shiue, S. K. Wu, and S. Y. Chen, "Infrared brazing of TiAl using Al-based braze alloys," Intermetallics, vol. 11, no. 7, pp. 661-671, 2003.

[36] A. F. Nesterov, "Formation of brazed joints in titanium brazed with an aluminium brazing alloy," Welding International, vol. 4, no. 3, pp. 213-215, 1990.

[37] W. Tillmann, M. Zimpel, N. F. L. Dias, J. Pfeiffer, L. Wojarski, and $\mathrm{Z}$. Xu, "Mechanical and microstructural analysis of ultrasonically assisted induction-brazed TiAl6V4 joints," Welding in the World, vol. 59, no. 6, pp. 901-909, 2015.

[38] A. Elrefaey, L. Wojarski, J. Pfeiffer, and W. Tillmann, "Preliminary investigation on ultrasonic-assisted brazing of titanium and titanium/stainless steel joints," Welding Journal, vol. 92, pp. 148-153, 2013.

[39] X. Chen, J. Yan, S. Ren, J. Wei, and Q. Wang, "Microstructure and mechanical properties of Ti-6Al-4V/Al1060 joints by ultrasonic-assisted brazing in air,” Materials Letters, vol. 95, pp. 197-200, 2013.

[40] M. K. Karfoul and A. S. Muhrat, "Low Melting Brazing Al$\mathrm{Cu}-\mathrm{Ni}$-Ti Filler Alloys Designed for Joining Titanium under Normal Ambient Air Conditions," in Proceedings of 10th International Conference Brazing, High Temperature Brazing and Diffusion Welding, vol. 293, pp. 17-21, Aachen, Germany, June 2013.

[41] R. Wells, "Low temperature large-area brazing of damage tolerant titanium structures," Welding Journal, vol. 54, no. 10, pp. 348-356, 1975. 
[42] C. T. Chang and R. K. Shiue, "Infrared brazing of Ti-6Al-4V using the Ti-15Cu-15Ni braze alloy," Journal of Materials Science, vol. 41, no. 7, pp. 2145-2150, 2006.

[43] American Welding Society (AWS) C3 Committee on Brazing and Soldering, Brazing Handbook, American Welding Society, Miami, FL, USA, 2007.

[44] H. Puga, J. Barbosa, J. C. Teixeira, and M. Prokic, "A new approach to ultrasonic degassing to improve the mechanical properties of aluminum alloys," Journal of Materials Engineering and Performance, vol. 23, no. 10, pp. 3736-3744, 2014.

[45] H. Puga, J. C. Teixeira, J. Barbosa, E. Seabra, S. Ribeiro, and M. Prokic, "The combined effect of melt stirring and ultrasonic agitation on the degassing efficiency of AlSi9Cu3 alloy," Materials Letters, vol. 63, no. 24-25, pp. 2089-2092, 2009.

[46] H. Puga, J. Barbosa, E. Seabra, S. Ribeiro, and M. Prokic, "The influence of processing parameters on the ultrasonic degassing of molten AlSi9Cu3 aluminium alloy," Materials Letters, vol. 63, no. 9-10, pp. 806-808, 2009.

[47] H. Xu, X. Jian, T. T. Meek, and Q. Han, "Degassing of molten aluminum A356 alloy using ultrasonic vibration," Materials Letters, vol. 58, no. 29, pp. 3669-3673, 2004.

[48] J. Barbosa and H. Puga, "Ultrasonic melt processing in the low pressure investment casting of $\mathrm{Al}$ alloys," Journal of Materials Processing Technology, vol. 244, pp. 150-156, 2017.

[49] H. Puga, J. Barbosa, S. Costa, S. Ribeiro, A. M. P. Pinto, and M. Prokic, "Influence of indirect ultrasonic vibration on the microstructure and mechanical behavior of $\mathrm{Al}-\mathrm{Si}-\mathrm{Cu}$ alloy," Materials Science and Engineering: A, vol. 560, pp. 589-595, 2013.

[50] L. Qingmei, Z. Yong, S. Yaoling, Q. Feipeng, and Z. Qijie, "Influence of ultrasonic vibration on mechanical properties and microstructure of $1 \mathrm{Cr} 18 \mathrm{Ni}$ Ti stainless steel," Materials \& Design, vol. 28, no. 6, pp. 1949-1952, 2007.

[51] D. Gao, Z. Li, Q. Han, and Q. Zhai, "Effect of ultrasonic power on microstructure and mechanical properties of AZ91 alloy," Materials Science and Engineering: A, vol. 502, no. 1-2, pp. 2-5, 2009.

[52] X. Chen, J. Yan, F. Gao, J. Wei, Z. Xu, and G. Fan, "Interaction behaviors at the interface between liquid Al-Si and solid Ti-6Al-4V in ultrasonic-assisted brazing in air," Ultrasonics Sonochemistry, vol. 20, no. 1, pp. 144-154, 2013.

[53] W. Cui, C. Wang, J. Yan, Z. Wang, and D. Wei, "Wetting and reaction promoted by ultrasound between sapphire and liquid Al-12Si alloy," Ultrasonics Sonochemistry, vol. 20, no. 1, pp. 196-201, 2013.

[54] H. Ji, X. Cheng, and M. Li, "Ultrafast ultrasonic-assisted joining of bare $\alpha$-alumina ceramics through reaction wetting by aluminum filler in air," Journal of the European Ceramic Society, vol. 36, no. 16, pp. 4339-4344, 2016.

[55] X. Chen, R. Xie, Z. Lai, L. Liu, G. Zou, and J. Yan, "Ultrasonicassisted brazing of Al-Ti dissimilar alloy by a filler metal with a large semi-solid temperature range," Materials \& Design, vol. 95, pp. 296-305, 2016.

[56] Y. Xiao, H. Ji, M. Li, and J. Kim, "Ultrasound-assisted brazing of $\mathrm{Cu} / \mathrm{Al}$ dissimilar metals using a $\mathrm{Zn}-3 \mathrm{Al}$ filler metal," Materials \& Design, vol. 52, pp. 740-747, 2013.

[57] W. Guo, T. Luan, J. He, and J. Yan, "Ultrasonic-assisted soldering of fine-grained 7034 aluminum alloys using $\mathrm{ZnAl}$ filler metals," Materials \& Design, vol. 125, pp. 85-93, 2017.

[58] W. Guo, X. Leng, T. Luan, J. Yan, and J. He, "Ultrasonicpromoted rapid TLP bonding of fine-grained 7034 high strength aluminum alloys," Ultrasonics Sonochemistry, vol. 36, pp. 354-361, 2017.
[59] W. L. Cotton, "report Effects of service environments on aluminum-brazed titanium (ABTi)," NASA Contractor Report 2943, Boeing Commercial Airplane Company, Seattle, Washington, USA, 1978.

[60] K. S. Suslick, D. A. Hammerton, and R. E. Cline, "Sonochemical hot spot," Journal of the American Chemical Society, vol. 108, no. 18, pp. 5641-5642, 1986.

[61] J. B. Jones, A. L. Fuchs, and W. R. Bailey, Ultrasonic Brazing Unit, US2833238, Serial No. 600198, USA, 1958.

[62] Z. Xu, J. Yan, G. Wu, X. Kong, and S. Yang, "Interface structure and strength of ultrasonic vibration liquid phase bonded joints of $\mathrm{Al}_{2} \mathrm{O}_{3 \mathrm{p}} / 6061 \mathrm{Al}$ composites," Scripta Materialia, vol. 53, no. 7, pp. 835-839, 2005.

[63] G. I. Eskin and D. G. Eskin, Ultrasonic Treatment of Light Alloy Melts, CRC Press, Boca Raton, FL, USA, 2014.

[64] M. A. Margulis and I. M. Margulis, "Mechanism of sonochemical reactions and sonoluminescence," High Energy Chemistry, vol. 38, no. 5, pp. 285-294, 2004.

[65] D. G. Shchukin, E. Skorb, V. Belova, and H. Möhwald, "Ultrasonic cavitation at solid surfaces," Advanced Materials, vol. 23, no. 17, pp. 1922-1934, 2011.

[66] S. Tamura and M. Hatakeyama, "The role of acoustic cavitation in liquid pressurization in narrow tubes," Journal of Applied Physics, vol. 113, no. 14, p. 144905, 2013.

[67] I. Hansson and K. A. Morch, "The dynamics of cavity clusters in ultrasonic (vibratory) cavitation erosion," Journal of Applied Physics, vol. 51, no. 9, pp. 4651-4658, 1980.

[68] Y. Li, X. Leng, S. Cheng, and J. Yan, "Microstructure design and dissolution behavior between $2024 \mathrm{Al} / \mathrm{Sn}$ with the ultrasonic-associated soldering," Materials \& Design, vol. 40, pp. 427-432, 2012.

[69] L. Ma, Z. Xu, K. Zheng, J. Yan, and S. Yang, "Vibration characteristics of aluminum surface subjected to ultrasonic waves and their effect on wetting behavior of solder droplets," Ultrasonics, vol. 54, no. 3, pp. 929-937, 2014.

[70] F. Zhang, S. L. Chen, Y. A. Chang, and U. R. Kattner, "A thermodynamic description of the Ti-Al system," Intermetallics, vol. 5, no. 6, pp. 471-482, 1997.

[71] C. Leyens and M. Peters, Titanium and Titanium Alloys: Fundamentals and Applications, Wiley-VCH, Weinheim, Germany, 2003.

[72] R. Pretorius, A. M. Vredenberg, F. W. Saris, and R. de Reus, "Prediction of phase formation sequence and phase stability in binary metal-aluminum thin-film systems using the effective heat of formation rule," Journal of Applied Physics, vol. 70, no. 7, pp. 3636-3646, 1991.

[73] M. Sujata, S. Bhargava, and S. Sangal, "On the formation of $\mathrm{TiAl}_{3}$ during reaction between solid $\mathrm{Ti}$ and liquid $\mathrm{Al}$," Journal of Materials Science Letter, vol. 16, no. 13, pp. 1175-1178, 1997.

[74] S. Wöhlert and R. Bormann, "Phase selection governed by different growth velocities in the early stages of the Ti/Al phase reaction," Journal of Applied Physics, vol. 85, no. 2, pp. 825-832, 1999.

[75] C. Michaelsen, S. Wöhlert, and R. Bormann, "Phase formation and microstructural development during solid-state reactions in Ti-Al multilayer films," MRS Proceedings, vol. 343, pp. 205-210, 1994.

[76] Z. G. Zhang, Y. J. Wang, L. J. Xiao, L. Q. Zhang, Y. Su, and J. S. Lin, "High-temperature oxidation of hot-dip aluminizing coatings on a $\mathrm{Ti}_{3} \mathrm{Al}-\mathrm{Nb}$ alloy and the effects of element additions," Corrosion Science, vol. 64, pp. 137-144, 2012.

[77] Z. G. Zhang, Y. P. Peng, Y. L. Mao, C. J. Pang, and L. Y. Lu, "Effect of hot-dip aluminizing on the oxidation resistance of 
Ti-6Al-4V alloy at high temperatures," Corrosion Science, vol. 55, pp. 187-193, 2012.

[78] L. Xu, Y. Y. Cui, Y. L. Hao, and R. Yang, "Growth of intermetallic layer in multi-laminated $\mathrm{Ti} / \mathrm{Al}$ diffusion couples," Materials Science and Engineering: A, vol. 435-436, pp. 638-647, 2006.

[79] J. G. Luo and V. L. Acoff, "Interfacial reactions of titanium and aluminum during diffusion welding," Welding Journal, vol. 79, no. 9, pp. 239s-243s, 2000.

[80] F. J. J. Loovan and G. D. Rieck, "Diffusion in the titaniumaluminium system-II. interdiffusion in the composition range between 25 and 100 at.\% Ti," Acta Metallurgica, vol. 21, no. 1 , pp. $73-84,1973$

[81] Y. Mishin and C. Herzig, "Diffusion in the Ti-Al system," Acta Materialia, vol. 48, no. 3, pp. 589-623, 2000.

[82] C. Buque and F. Appel, "Diffusion bonding of gamma-based titanium aluminides," Zeitschrift für Metallkunde, vol. 93, no. 8, pp. 784-789, 2002.

[83] D. Herrmann and F. Appel, "Diffusion bonding of $\gamma$ (TiAl) alloys: influence of composition, microstructure, and mechanical properties," Metallurgical and Materials Transactions A, vol. 40, no. 8, pp. 1881-1902, 2009.

[84] Y. Flom, "Electron Beam Brazing of Titanium for Construction in Space," in Proceedings of The Third International Brazing and Soldering Conference (Brazing and Soldering), pp. 1-5, ASM International, San Antonio, TX, USA, April 2006.

[85] S. W. Kim, D. H. Kim, B. D. You, J. W. Han, and M. S. Kim, "Evaporation behavior of magnesium under reduced pressure," Materials Science Forum, vol. 439, pp. 238-243, 2003.

[86] W. L. Winterbottom and G. A. Gilmour, "Vacuum brazing of aluminum: auger studies of wetting and flow characteristics," Journal of Vacuum Science and Technology, vol. 13, no. 2, pp. 634-643, 1976.

[87] O. Ohashi and K. Sasabe, "Effect of alloying elements on the behaviour of oxide films at diffusion-welded interfaces of aluminium alloys-study of surface films at diffusion-welded interfaces (report 4)," Welding International, vol. 4, no. 10, pp. 775-780, 1990.

[88] F. Cverna, ASM Ready Reference: Thermal Properties of Metals, ASM International, Materials Park, OH, USA, 2002.

[89] S. Y. Chang, L. C. Tsao, Y. H. Lei, S. M. Mao, and C. H. Huang, "Brazing of 6061 aluminum alloy/Ti-6Al-4V using Al-Si$\mathrm{Cu}-\mathrm{Ge}$ filler metals," Journal of Materials Processing Technology, vol. 212, no. 1, pp. 8-14, 2012. 


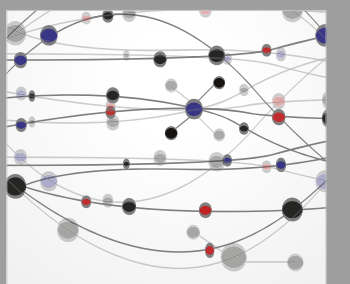

The Scientific World Journal
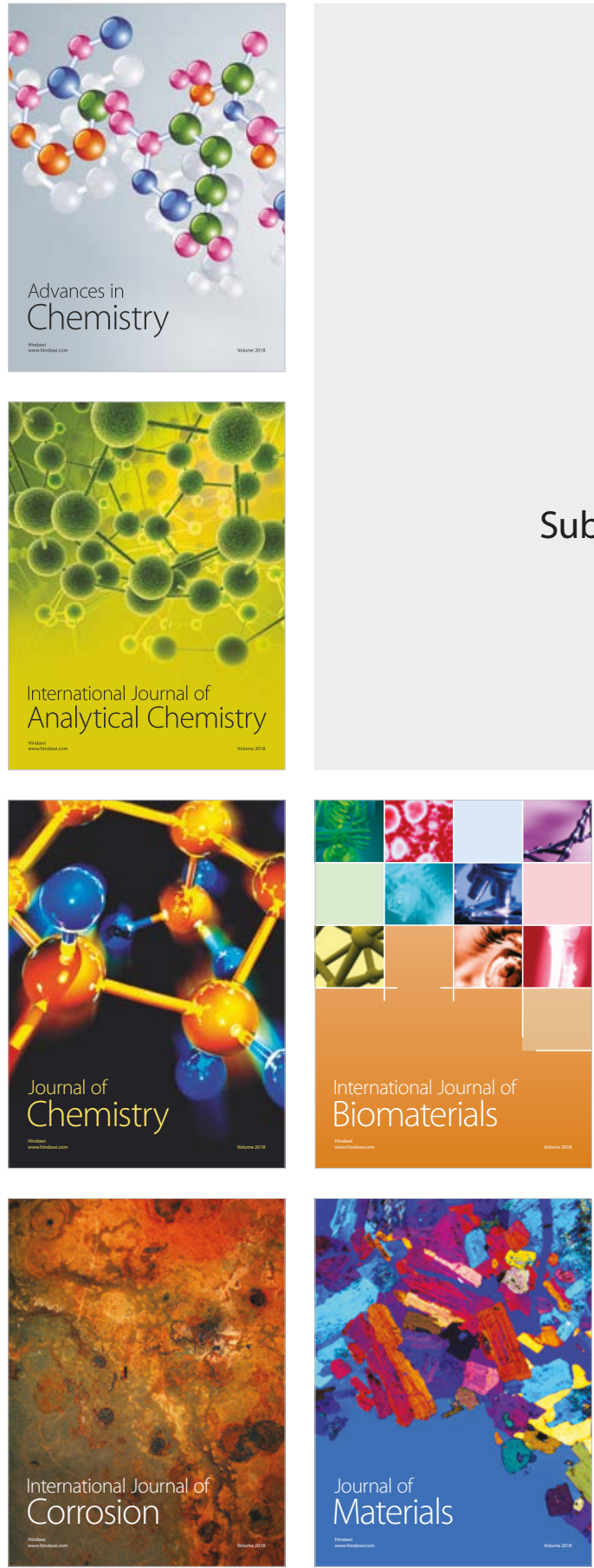

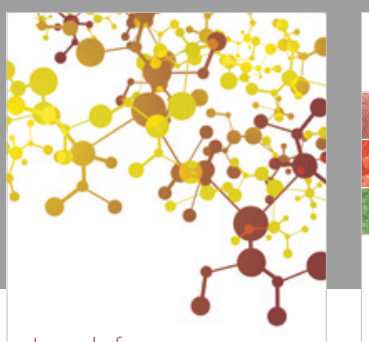

Journal of

Applied Chemistry
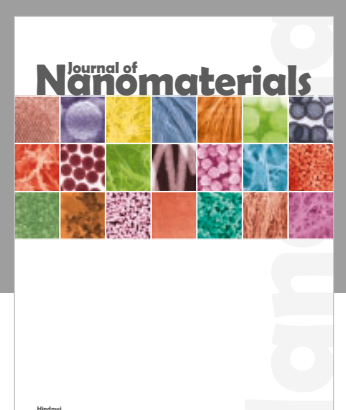

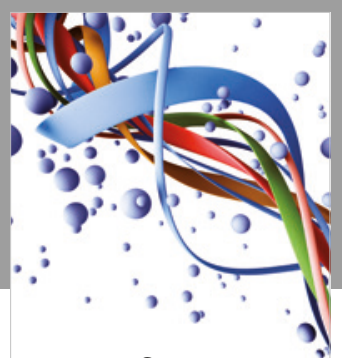

Scientifica

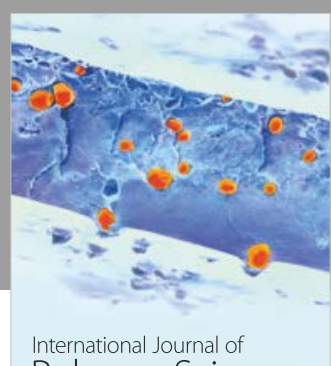

Polymer Science

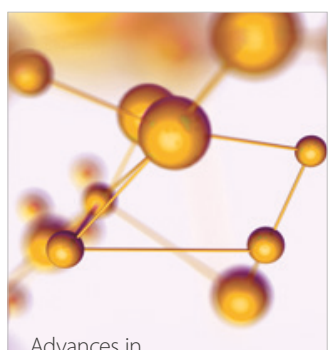

Physical Chemistry
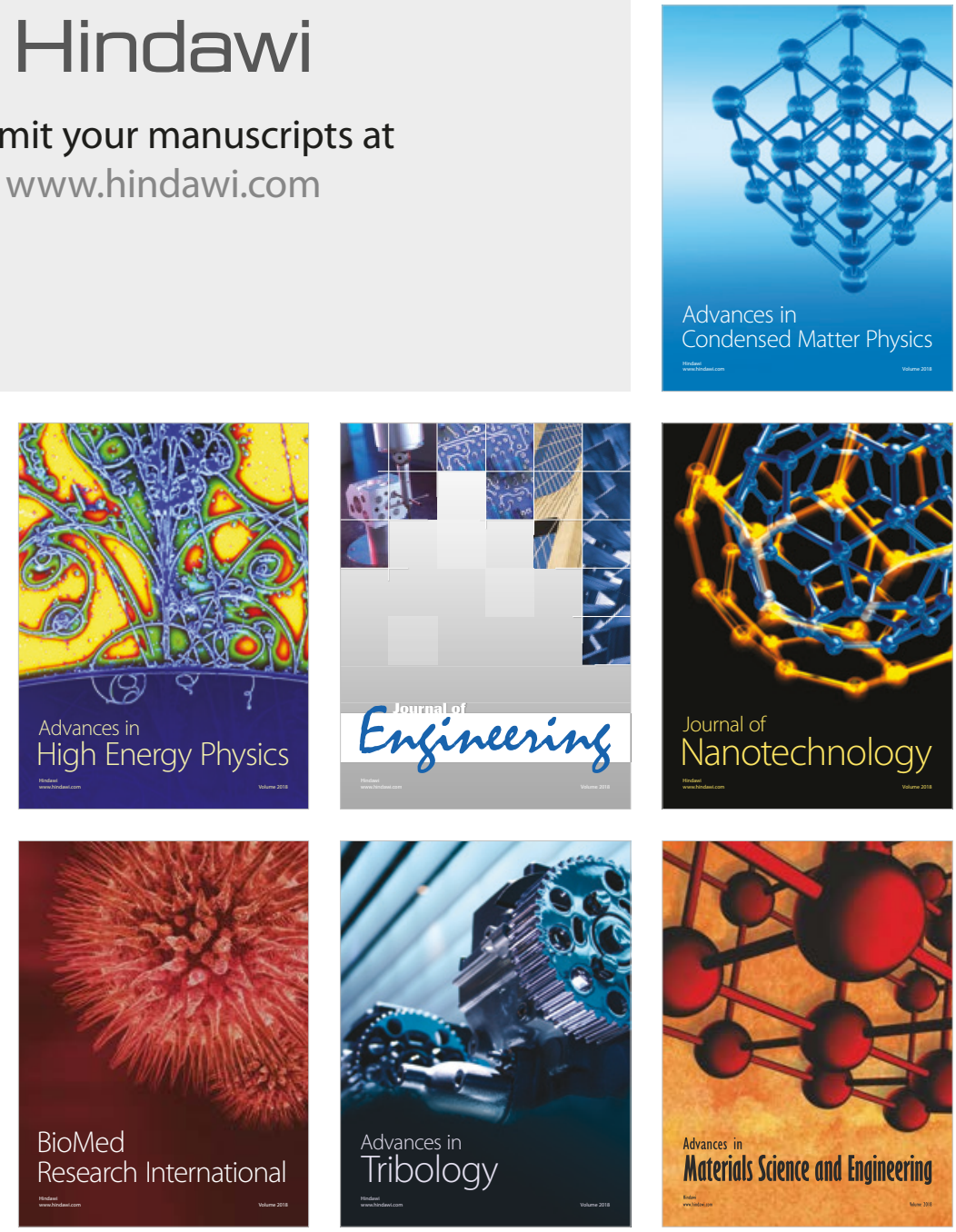